Discussion Paper No. 14-073

\title{
Extending Taxation of Interest and
} Royalty Income at Source - an Option to Limit Base Erosion and Profit Shifting?

Katharina Finke, Clemens Fuest, Hannah Nusser, and Christoph Spengel

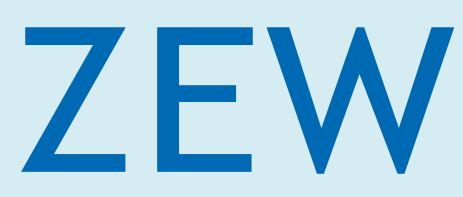

Zentrum für Europäische Wirtschaftsforschung $\mathrm{GmbH}$ Centre for European Economic Research 
Discussion Paper No. 14-073

\title{
Extending Taxation of Interest and Royalty Income at Source - an Option to Limit Base Erosion and Profit Shifting?
}

\author{
Katharina Finke, Clemens Fuest, \\ Hannah Nusser, and Christoph Spengel
}

Download this ZEW Discussion Paper from our ftp server:

http://ftp.zew.de/pub/zew-docs/dp/dp14073.pdf

Die Discussion Papers dienen einer möglichst schnellen Verbreitung von neueren Forschungsarbeiten des ZEW. Die Beiträge liegen in alleiniger Verantwortung der Autoren und stellen nicht notwendigerweise die Meinung des ZEW dar.

Discussion Papers are intended to make results of ZEW research promptly available to other economists in order to encourage discussion and suggestions for revisions. The authors are solely responsible for the contents which do not necessarily represent the opinion of the ZEW. 


\title{
Extending taxation of interest and royalty income at source - an option to limit base erosion and profit shifting? ${ }^{\ddagger}$
}

\author{
Katharina Finke*, Clemens Fuest**, \\ Hannah Nusser*** and Christoph Spengel ${ }^{* * * *}$
}

September 2014

\begin{abstract}
This paper discusses tax policy measures to reduce corporate tax avoidance by extending taxation in the source country without imposing double taxation. We focus on four options: Bilaterally restricting interest and royalty deductibility, introducing an inverted tax credit system, levying withholding taxes on all interest and royalty payments and levying withholding taxes as an anti-avoidance regulation. We calculate the tax revenue effects of introducing a minimum withholding tax on royalty payments and an inverted tax credit. For the withholding tax we find that the US would suffer the greatest tax revenue losses, while some other countries would increase their tax revenue. In general, gains and losses depend not only on net balances in royalty income flows but also on withholding tax and credit rules under the status quo. The inverted tax credit would increase tax revenue in particular in high-tax countries. Revenue redistribution would only arise if withholding taxes were replaced by the inverted credit.
\end{abstract}

JEL Classification: H20, H21, H 32, F23, K34

Keywords: profit shifting; multinational firm; source taxation; tax policy; tax reform; optimal taxation

\footnotetext{
$\ddagger$ This research is part of the MannheimTaxation (MaTax) ScienceCampus, funded by the Leibniz Association, the State of Baden-Württemberg, and the participating institutions ZEW and University of Mannheim.

* ZEW Mannheim

** ZEW Mannheim \& University of Mannheim

*** University of Mannheim

**** University of Mannheim \& ZEW Mannheim
} 


\section{Introduction}

Intra-group debt financing and licensing strategies play an important role in the current debate on tax avoidance by multinational firms. In the last two decades, many countries have taken measures to limit tax avoidance of multinational companies. This includes various forms of thin capitalization rules; currently there is a debate about extending this approach to royalty payments. These measures essentially aim at making profit shifting more difficult by extending taxation in the source country. ${ }^{1}$ A key issue in the debate about anti-tax-avoidance policies is that unilateral measures may easily give rise to double taxation and may also have unintended side effects on companies that do not engage in profit shifting. Many existing tax avoidance measures have been introduced unilaterally and little or nothing has been done to avoid double taxation. In this paper, we focus on measures, which avoid double taxation and discuss the degree of international cooperation required to achieve this.

The purpose of this paper is twofold. Firstly, we provide an overview over current tax rules regarding the taxation of interest and royalty payments in the source countries. Secondly, we discuss reform options that extend taxation in the source country while avoiding double taxation. $^{2}$ We consider four types of measures:

1. Internationally coordinated interest and royalty deduction limitations

2. Inverted tax credits

3. Withholding taxes on all interest and royalty payments

4. Withholding taxes as an anti-tax-avoidance regulation

The proposal to extend the taxation of interest and royalty payments in the source country raises various issues. First, one may ask whether more source-based taxation is an effective instrument to fight profit shifting. Second, higher taxes levied at source may have adverse effects on investment incentives for companies. Third, more source-based taxation may change the incentives of countries in tax competition for real economic activity. Fourth, ex-

\footnotetext{
${ }^{1}$ In its initiative against base erosion and profit shifting (BEPS) the OECD also proposes to 'limit base erosion via interest deductions and other financial payments', see OECD (2013).

2 This paper also contributes to the ongoing work of OECD Working Party 6 and 11 on Action 4 "Limit base erosion via interest deductions and other financial payments" of the OECD Action Plan on Base Erosion and Profit Shifting (BEPS), see OECD (2013). The results of this work are expected to be presented by the OECD in September 2015. In an earlier paper (Fuest et al. (2013)), we argue that one option to tackle profit shifting via interest and license payments between group companies is to strengthen source taxation of this income, in particular by reintroducing creditable withholding taxes.
} 
tending source taxation while avoiding double taxation implies a redistribution of taxing rights. Little is known about the tax revenue consequences of this redistribution.

The main findings of our analysis are as follows. First, we show that existing tax avoidance legislation includes a variety of measures limiting the deductibility of interest payments. Compared to this, anti-tax-avoidance legislation regarding royalties is much less developed and mostly limited to transfer pricing policies. Instead, many countries have introduced special tax regimes like IP Boxes to attract immaterial assets. Second, a brief literature survey shows that empirical studies on the impact of measures like thin capitalization rules or tighter transfer pricing policies find these policies to be effective in reducing profit shifting. Of course, the current debate suggests that there are still major loopholes in the international tax system. However, there is empirical evidence which suggests that anti-tax-avoidance measures do induce multinational companies to invest less. In addition, while the impact of more source-based taxation is difficult to investigate empirically, several theoretical studies show that crowding back profit shifting through more source-based taxation in high-tax countries may lead to more aggressive tax competition for real economic activity. Third, we present and discuss different options for extending taxation of interest and royalties at source, which all avoid double taxation. Fourth, we use OECD data on country-by-country flows of royalty payments to shed some light on the tax revenue consequences of introducing i) general withholding taxes of $10 \%$ in all OECD and EU member states and ii) a system of inverted tax credit.

Our calculations confirm that a broad introduction of withholding taxes on royalties will lead to a significant redistribution of tax revenue. The U.S. would suffer the biggest fiscal loss. This reflects that the country is a net recipient of royalty payments. However, not all countries where royalty income exceeds payments would lose tax revenue. The reason is that such a reform would change existing withholding tax and credit rules, which provide for different tax rates dependent on the partner country. Implementing an inverted tax credit system would especially benefit some high-tax countries and would redistribute tax revenue if levying withholding taxes was fully replaced. Due to data limitations, our calculations only include 12 countries and some strong assumptions must be made. Among other things, we abstract from behavioral changes. It is important to take these limitations into account when interpreting the results of our calculations. 
The paper is organized as follows: Section 2 discusses how the present interplay of source and residence taxation creates possibilities for tax planning in the field of intra-group financing and licensing. In Section 3 we provide a brief overview of ways in which countries currently try to limit interest and royalty deductions to prevent profit shifting. Section 4 briefly summarizes empirical evidence on the effectiveness of existing anti-tax-avoidance policies and on the impact of these policies on investment. We also refer to theoretical studies about the impact of anti-tax-avoidance measures on tax competition. In Section 5, we describe and discuss the four reform options mentioned above. Section 6 analyses the impact of higher sourcebased taxes on tax revenues of different countries using data on royalty flows between countries available from the OECD.Stat database. Section 7 concludes.

\section{Tax planning with debt financing and licensing}

The allocation of taxing rights between jurisdictions differs with respect to the type of income. Generally, business profits are taxed at source whereas factor remunerations like interest and royalty payments are deductible at source and taxed in the residence country of the recipient. Yet, within certain limits, the source country may levy withholding taxes on outgoing payments. These withholding taxes are then usually credited against the tax liability in the residence country. Within the European Union (EU), however, the Interest and Royalties Directive (IRD), ${ }^{3}$ which was introduced in 2003 with the aim of reducing tax obstacles between member states, bans the levying of withholding taxes in case of transactions between at least $25 \%$ associated companies.

The existing system of allocating taxing rights gives rise to tax planning opportunities for multinational firms, as it allows multinationals to choose between the tax rate applicable at source or at residence. For example, it is tax-efficient for multinationals to finance group companies in high-tax countries with intra-group debt from affiliates residing in low-tax countries. Another tax planning strategy is to locate intangible property in a group company resident in a low-tax country and license it to group companies residing in high-tax countries. As nominal tax rates differ significantly across important business locations, the tax advantage arising from profit shifting is often substantial. Sometimes multinational firms may

\footnotetext{
${ }^{3}$ Directive 2003/49/EC.
} 
even push their overall tax burden to levels close to zero. ${ }^{4}$ They can achieve this, for instance, by locating financing and IP-Holding corporations in typical tax havens that do not levy corporate income tax or in countries that generally levy (high) profit taxes but offer special tax rules resulting in far lower effective tax rates for interest and royalty income. Examples for the latter are intellectual property (IP) Box regimes ${ }^{5}$ or the notional interest deduction regime in Belgium. ${ }^{6}$ By shifting profits of operating companies as interest and royalty payments to these financing and IP-Holding companies, the profits remain de facto untaxed or are subject to very low taxation, provided that withholding taxes can be avoided. This is the case for qualifying payments between EU member states or if the source country does not levy withholding taxes according to domestic or treaty law. Moreover, intra-group interest and royalty payments may be channeled via conduit companies (treaty shopping/directive shopping) to circumvent withholding taxes.

Of course, the extent to which multinational firms can implement the described profit shifting strategies in practice depends on their group structure, the scale of activities in each country, the relevance and value of IP as well as the anti-avoidance regulations of tax administrations. Clearly, in many profit shifting strategies, the absence of source taxation of interest and royalty payments plays a key role. This is why the extension of source taxation on these income flows is an important starting point for efforts to limit profit shifting.

\section{The taxation of interest and royalties at source: current country practice}

In the past two decades, most developed countries have introduced regulations that aim to restore some taxing rights for interest and royalty payments at source to protect tax revenue.

Almost all countries have transfer pricing rules based on the arm's length principle for intragroup transactions in place. ${ }^{7}$ According to the arm's length principle, the price for transactions between related companies should be equal to the price that independent parties would have agreed on. If a country applies the arm's length principle, royalties and interest payments are only tax deductible up to the arm's length price. However, in many cases no comparable

\footnotetext{
${ }^{4}$ As shown by prominent examples like Google or Amazon. For an overview of effective tax rates of prominent multinationals, see Sullivan (2012), p.655; for a detailed description of Google's tax planning structure, see Kleinbard (2011); Sandell (2012). Amazon applies a tax structure comparable to the IP-Holding structure depicted in Fuest et al. (2013), p. 312-313.

${ }^{5}$ For an overview of IP Box regimes in Europe, see Evers et al. (2014).

${ }^{6}$ See also Kalloe (2011), p. 506.

${ }^{7}$ For an overview on country practice, see Zinn et al. (2014).
} 
transactions between unrelated parties exist, in particular for royalty payments because these payments are usually related to immaterial property which is unique. For interest income, similar difficulties arise because a large range of levels of debt and corresponding interest rates may be justifiable. ${ }^{8}$ Hence, possibilities for extensive profit shifting remain for both intragroup royalty and interest payments despite the application of transfer pricing rules.

In addition to transfer pricing rules, an increasing number of countries apply regulations limiting interest deductibility. The precise regulations differ across countries and have changed over time. Figure 1 gives an overview of current country practices in all EU member states and selected third countries. ${ }^{9}$

Figure 1: Overview of regulations limiting interest deduction in $2014^{10}$

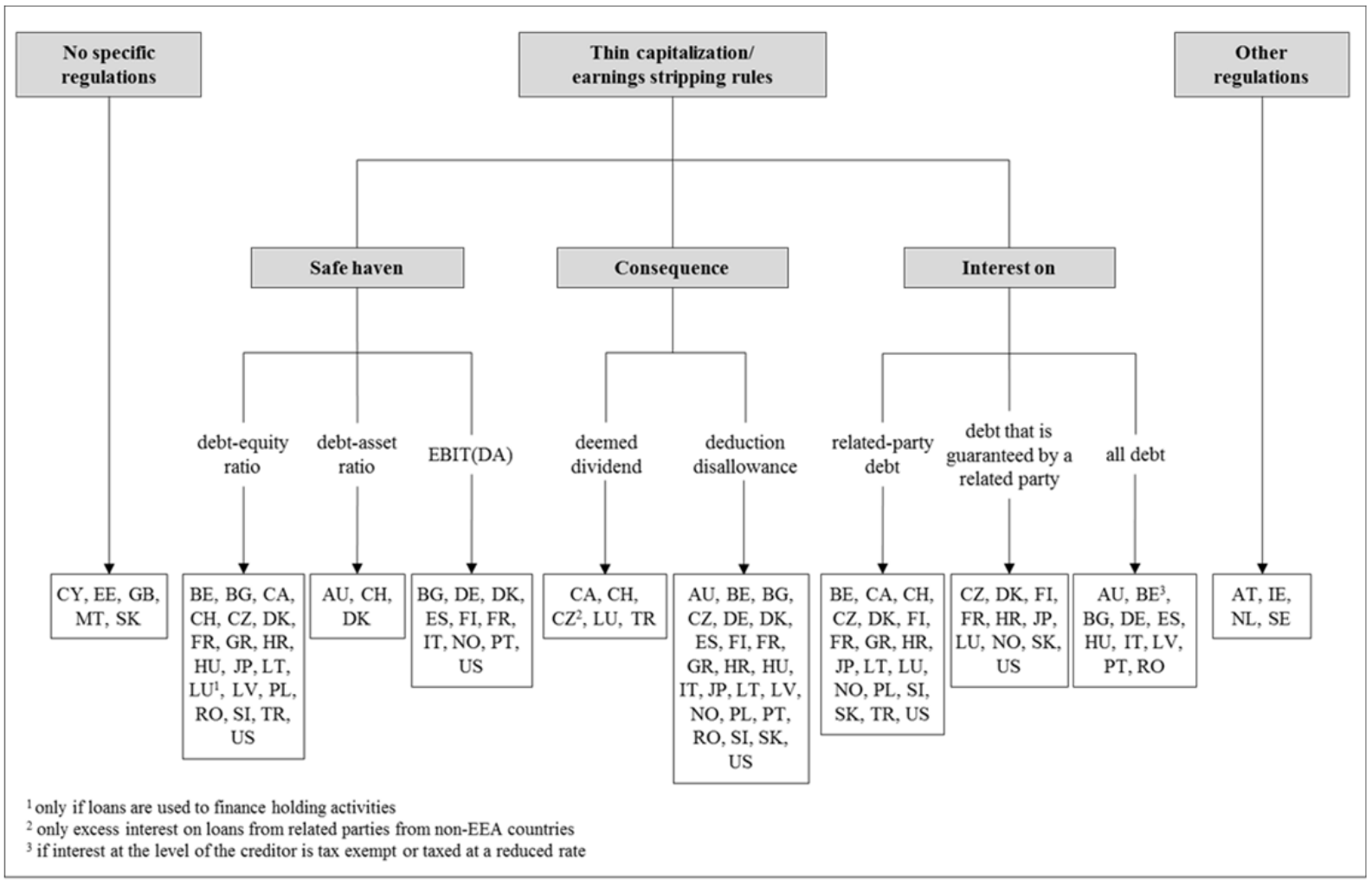

The countries that do not stipulate specific regulations to limit interest deduction usually include the case of excessive debt financing in transfer pricing or general anti-avoidance regulations (GAAR).

\footnotetext{
${ }^{8}$ See also Burnett (2014), pp. 62-63 and 70.

${ }^{9}$ For a comparison of country practice with respect to regulations limiting the deductibility of interest at source, see also Webber (2010); Henry et al. (2008); Bohn (2009).

${ }^{10}$ The figure is based on data taken from the IBFD.
} 
Thin capitalization or earnings stripping rules differ with respect to the defined acceptable level up to which interest expenses are fully deductible. This safe haven ${ }^{11}$ either refers to a predefined debt-to-equity ratio or debt-to-asset ratio (thin capitalization rules), or to the relation between earnings before interest and taxes (EBIT) or earnings before interest, taxes, depreciation and amortization (EBITDA) and interest expenses (earnings stripping rules). Under the debt-to-equity criterion, interest expenses are fully deductible as long as the debt-to-equity ratio does not exceed a certain threshold. Interest related to any excess debt is not deductible. However, in some countries that apply a debt-to-equity ratio, companies may also deduct the excess debt if they demonstrate that it is at arm's length. ${ }^{12}$ Countries that apply a debt-to-asset ratio allow a full deduction of interest only as long as to the extent that the debt is within the asset-based ratio. If the safe haven is defined with respect to some profit measure, net interest expenses are deductible as long as they do not exceed a certain share of profits (e.g., 30\% of EBITDA in Germany). Some countries, such as France, the United States and Denmark, use two or all three criteria in combination. In France, moreover, only $75 \%$ of the net financial expenses on both intra-group and third party debt are deductible. This measure only applies to the deductible part of the interest payments after application of the other interest deduction rules.

If the regulation is binding, a second dimension in which the thin capitalization and earnings stripping regulations differ is the treatment of disqualified interest expenses. In some countries these are considered as hidden profit distributions and therefore reclassified as deemed dividends. Re-characterizing disqualified interest expense ensures that the tax treatment in the hands of the creditor corresponds to the treatment at the level of the debtor and that the interest is thus not taxed twice. In the international setting, of course, this can only be achieved if the residence country of the creditor endorses this re-classification. In most countries, disqualified interest expense is considered as a non-deductible interest expense, thus potentially resulting in a double taxation of the underlying interest even in a domestic setting. However, in some countries (e.g., Germany), non-deductible interest expenses can be carried forward for a number of years. Especially in cases where the deductibility is defined with respect to a volatile measure such as EBIT(DA), this seems reasonable to mitigate business-cycle effects.

\footnotetext{
11 Please note that although the term safe haven often refers to regulations applying fixed debt-to-equity ratios while still allowing excess interest deductions that are proven to be at arm's length, we use it in a broader sense here.

${ }^{12}$ See also Burnett (2014), p. 54.
} 
Finally, the regulations can be distinguished with respect to the scope of debt concerned. Some countries include only related-party debt or debt that a related party guarantees for. The rationale is that this includes financing contracts that are most likely to be influenced by tax planning considerations because they are controlled by the group. Other countries extend the regulation to all debt and hence do not only target intra-group profit shifting but also the general tax incentive for debt financing, which is already present in a purely domestic setting.

With respect to royalty payments, countries usually do not apply comparable deduction limitation rules.

Some countries do not have general thin capitalization or earnings stripping rules but make use of regulations denying the deductibility of interest payments in specific cases. In Austria, for example, interest is qualified as a hidden profit distribution if the level of equity is inadequate. Moreover, with effect from March 2014, interest and royalties paid to related companies are not deductible if the income is subject to an effective taxation at a rate of less than 10 $\%$ at the level of the recipient. In addition to its thin capitalization rules, France applies two other rules limiting interest deductibility. If the net financial expenses exceed 3 Million euros, only $75 \%$ of the total net financial expenses on both intra-group and third party debt are deductible for tax purposes. Moreover, interest is not deductible if the tax paid by the lender is lower than $25 \%$ of the French corporate income tax. Ireland treats interest as a hidden profit distribution if it is not paid in the course of trade to a Non-EU foreign company which is a 75\% affiliate. Additionally, interest is insofar not deductible as it exceeds a (difficult to determine) normal commercial rate. The Netherlands abolished their thin capitalization rules in 2013 and now apply several complex highly specific interest deduction restriction rules. In Sweden, interest paid to affiliated companies is not deductible if the interest income is taxed at a rate of less than $10 \%$ at the level of the recipient, unless the recipient is resident in an EU member state or treaty state and the loan is motivated by business reasons. In addition, Sweden denies the deduction of interest paid to affiliates even if the income is taxed at a rate of at least $10 \%$ in case the main reason for the underlying loan is to obtain a substantial tax benefit.

A problem of all interest deduction limitation rules based on a fixed ratio is the impossibility to define one ratio that is appropriate for all kinds of businesses. Hence, thin capitalization and earnings stripping rules are usually quite broad in their general application and not limited solely to aggressive tax planning. As a consequence, escape clauses, like for example de min- 
imis rules or rules exempting companies with a lower ratio of equity to assets than the ratio of the worldwide group, as currently applied in Germany, may be necessary. Escape clauses, however, increase the complexity of thin capitalization and earnings stripping rules and provide loopholes for multinationals to circumvent the application of the underlying rules.

Besides limiting the possibility to deduct interest and license expenses, levying withholding taxes on interest and royalties is another way to ensure source taxation. Due to the EU Interest and Royalties Directive, however, there is virtually no withholding tax on interest and royalty payments resulting from intra-group transactions within Europe. With respect to third countries, the country practice differs. As illustrated by Figure 2 and Figure 3, a number of countries do not provide for withholding taxes on interest and royalty income earned by foreigners under domestic law. Other countries levy withholding taxes on foreign interest and royalties at differing rates. These rates are usually in a range corresponding with the applicable corporate income tax rates and are reduced under tax treaties. Some countries have specific withholding tax rules for interest and royalty income paid to group entities resident in special lowtax jurisdictions. The Czech Republic and Romania, for example, apply a higher withholding tax rate on interest and royalty payments if the receiving company is resident in a country, with which it does not have a treaty or an information exchange agreement in place. Croatia levies a higher withholding tax if there is no treaty with the residence country of the receiving company and if the tax level of the residence country is below a certain threshold. The same holds true for interest payments in Denmark. Portugal, France and Latvia apply higher withholding tax rates for interest and royalty payments made to residents of a listed tax haven. 
Figure 2: Withholding tax rates on interest income in domestic tax law in all EU member states and selected third countries (2014) $)^{13}$

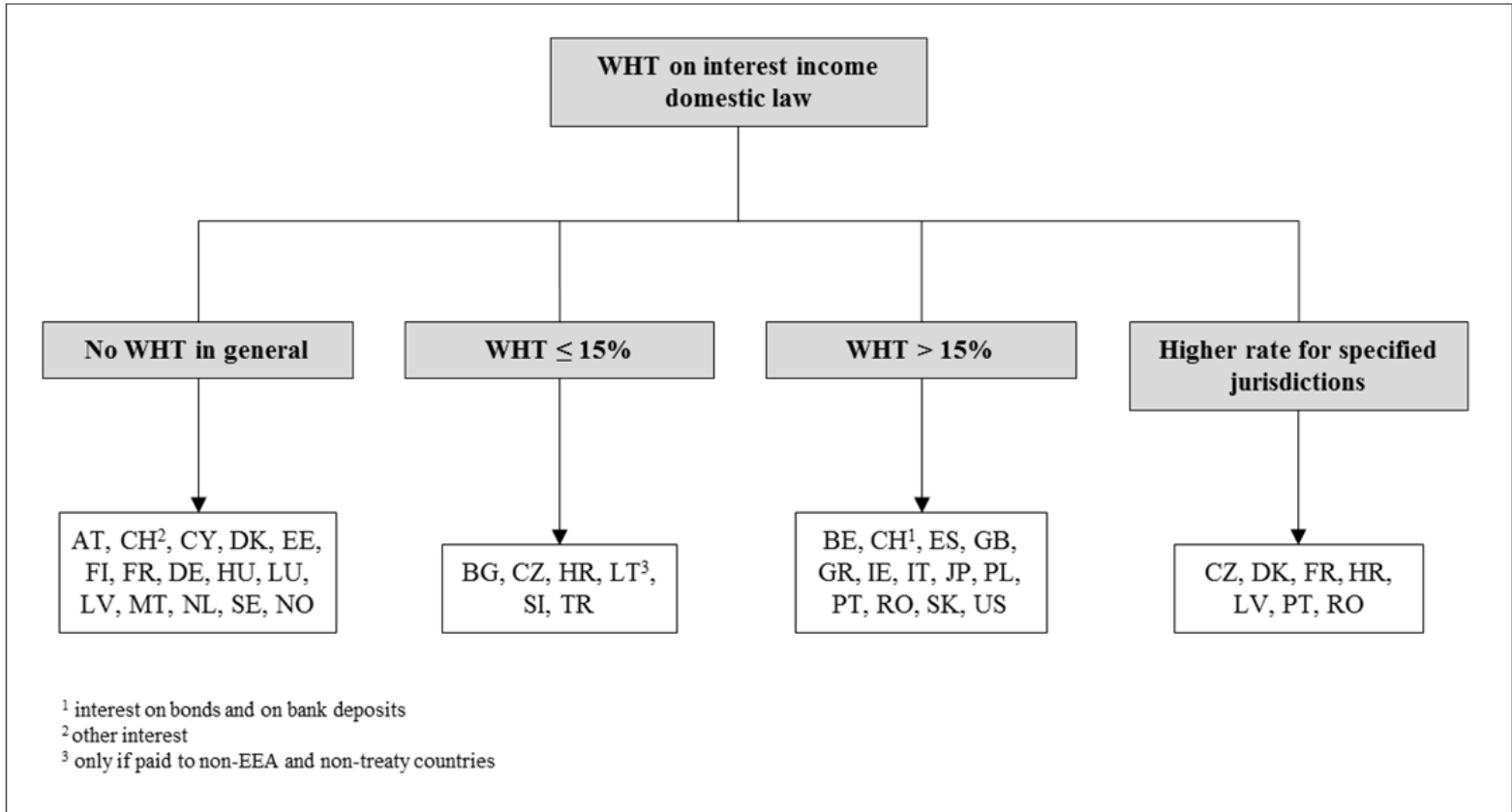

Figure 3: Withholding tax rates on royalty income in domestic tax law in all EU member states and selected third countries (2014) $)^{14}$

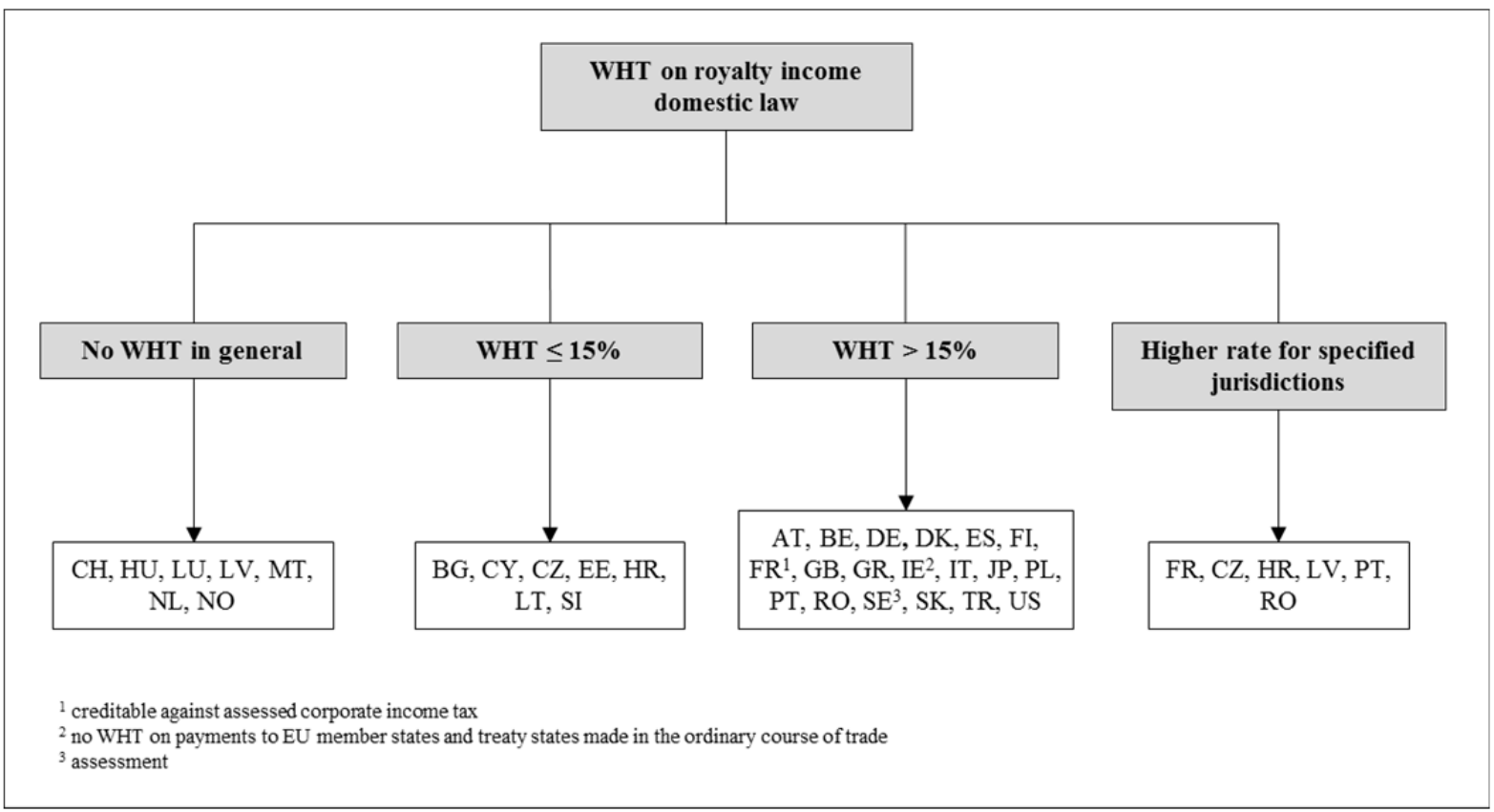

13 The figure is based on data taken from the IBFD.

14 The figure is based on data taken from the IBFD. 


\section{Empirical evidence and theoretical findings}

There is a growing number of empirical studies showing that the capital structure of multinational firms is indeed tax-sensitive. ${ }^{15}$ In a meta-study, Feld et al. survey 48 empirical studies on the relationship between taxation and capital structure choices. ${ }^{16}$ Across all studies, they find a significant relationship between tax incentives and firms' capital structure. Accounting for different study characteristics, they predict a marginal tax effect on the debt ratio of about 0.27 . Hence, an increase of the tax rate differential by one percentage point results in an increase of the debt ratio by 0.27 percentage points.

Concerning intra-group licensing, Dischinger and Riedel ${ }^{17}$ and Karkinsky and Riedel ${ }^{18}$ provide evidence that the location of intellectual property is influenced significantly by tax considerations. Moreover, it has been shown that research and development (R\&D)-intensive multinationals engage in a higher volume of intercompany transactions and they disproportionally often invest in countries with both very high and very low tax rates, which offer incentives to shift profits either out or in. ${ }^{19}$

With respect to the efficiency of existing countermeasures, Lohse and Riedel provide evidence that profit shifting activities of EU multinationals have significantly declined since the introduction or tightening of transfer price documentation requirements. ${ }^{20}$ Buettner et al. use data on subsidiaries owned by German multinationals and located in Europe and OECD member states. The data covers the time period from 1996-2004. ${ }^{21}$ This study shows that the introduction of thin capitalization regulations with a debt-to-equity ratio of 2:1 in a country with a tax rate of $34 \%$ (sample average tax rate) reduces the share of internal debt by 3.2 percentage points if the debt-to-equity ratio refers to internal debt and 6.6 percentage points if the debt-to-equity ratio refers to total debt. Based on data for the years 1982-2004, Blouin et al. provide evidence for a reduction of internal and total debt of foreign U.S. affiliates in response to thin capitalization rules. ${ }^{22}$ Moreover, several studies specifically investigating the effects of the former German thin capitalization rules, which applied before $2008^{23}$ and of the

\footnotetext{
${ }^{15}$ See e.g. Desai et al. (2004); Huizinga et al (2008).

${ }^{16}$ Feld et al. (2013).

${ }^{17}$ Dischinger/Riedel (2011).

${ }^{18}$ Karkinsky/Riedel (2012).

${ }^{19}$ Grubert (2003).

${ }^{20}$ Lohse/Riedel (2013).

${ }^{21}$ Buettner et al. (2012).

22 Blouin et al. (2014).

${ }^{23}$ See Weichenrieder/Windischbauer (2008); Wamser (2008); Overesch/Wamser (2010).
} 
new earnings stripping rules implemented in $2008^{24}$ provide evidence for reduced internal debt-to-asset ratios and thus the efficiency of both types of interest deduction limitations. ${ }^{25}$

An earlier version of the study of Buettner et al. ${ }^{26}$ also highlights a potentially important trade-off between stricter anti-avoidance measures and real economic activity. They estimate that repealing the thin capitalization rules would on average increase investment by $4.8 \%$. In a more recent paper, Buettner et al. find that the tax rate sensitivity of foreign direct investment is about twice as large in the presence of a typical thin capitalization rule with a debt-to-equity ratio of 3:1 as compared to the case that no such restriction applies. ${ }^{27}$ The negative impact on investments is corroborated by Overesch who shows that the possibility of profit shifting makes investments by multinational firms less sensitive to domestic tax rates. ${ }^{28}$ Moreover the above-mentioned finding of Grubert ${ }^{29}$, according to which $\mathrm{R} \& \mathrm{D}$-intensive multinationals are attracted by countries with very high and very low tax levels, suggests that limiting profit shifting opportunities in high-tax countries may negatively affect real investment. ${ }^{30}$

Another question is how the tax policy incentives for countries are related to anti-taxavoidance measures? In that respect three arguments play a role. Firstly, one may ask why countries currently fail to levy effective source-based taxes on interest and royalty payments to tax havens. Johannesen ${ }^{31}$ uses a theoretical model of tax competition to show that under the EU Interest and Royalties Directive individual EU countries have incentives to levy low or no withholding taxes at all on payments to third countries, as this allows them to attract business, with the consequence that other EU countries cannot protect themselves against profit shifting to tax havens. This suggests that common rules regarding source taxes on payments to third countries would be needed to complement the Directive. Secondly, Hong and Smart ${ }^{32}$, reinterpreting an argument by $\mathrm{Keen}^{33}$, argue that limiting profit shifting of multinational companies may intensify tax competition because profit shifting can be seen as a form of price dis-

\footnotetext{
${ }^{24}$ See Buslei/Simmler (2012); Dreßler/Scheuering (2012).

${ }^{25}$ For an overview on these studies, see Ruf/Schindler (2012).

${ }^{26}$ Buettner et al. (2008).

${ }^{27}$ Buettner et al. (2014).

${ }^{28}$ Overesch (2009).

${ }^{29}$ Grubert (2003).

${ }^{30}$ Not all empirical studies confirm this finding. Weichenrieder and Windischbauer, for example, conducted a study based on data on inbound investment to Germany from the MIDI database and found that the German thin capitalization rules implemented before 2008 were effective in reducing profit shifting while not affecting real investment (Weichenrieder/Windischbauer (2008)). This result might, however, be influenced by another finding of the study, which is that multinationals used loopholes to avoid the application of thin capitalization rules.

31 Johannesen (2012).

32 Hong/Smart (2010).

${ }^{33}$ Keen (2001).
} 
crimination between more and less mobile tax bases. ${ }^{34}$ Not allowing this price discrimination may force countries to reduce the tax burden on all firms. Finally, Becker and Fuest ${ }^{35}$ show that tighter transfer pricing policies by high-tax countries, which effectively lead to more taxation in the source country, may lead to more aggressive tax rate competition by low-tax countries. The reason is that the decline in the tax base of low-tax countries reduces their marginal cost of reducing tax rates further.

To sum up, the empirical and theoretical studies cited above suggest three conclusions. First, tighter transfer pricing regulations and thin capitalization or earnings stripping rules are effective in reducing profit shifting activities. Whether they are effective enough, though, is another question. Second, there is some evidence suggesting that measures against profit shifting might come at the cost of reduced investment. Third, a shift to more source-based taxation may change the tax policy incentives for countries. In particular, it cannot be excluded that tax competition for real economic activity may become more intense.

\section{Reform options for extending source taxation}

In this section we present and discuss four options to strengthen source taxation. All of them are based on the internationally accepted principle of avoiding double taxation: bilateral interest and royalty deduction limitations, an inverted tax credit, withholding taxes on all interest and royalty payments and withholding taxes as an anti-avoidance regulation.

The options differ in the extent to which they limit profit shifting. Which measure is most adequate therefore, first of all, depends on what specific aim countries want to achieve by strengthening source taxation: Is the purpose to generally change the allocation of taxing rights and extend taxing rights of source countries? Or do countries only want to guarantee a certain minimum tax level for profits of multinationals? Should this minimum level be determined by the tax level in the source country?

As a consequence of the different scopes of the reform options, they also have different tax revenue effects. Moreover, the reforms are likely to have different effects on real investment and differ with respect to the required level of cooperation.

\footnotetext{
${ }^{34}$ For a more critical view of income shifting see Slemrod/Wilson (2009).

35 Becker/Fuest (2012).
} 
Figure 4 summarizes the basic concepts, scope, tax revenue consequences, impact on real investment and the required level of cooperation of all options, which we will discuss in detail below.

Figure 4: Comparison of the reform options

\begin{tabular}{|c|c|c|c|}
\hline \multicolumn{4}{|c|}{$\begin{array}{l}\text { Objective: } \\
\text { Reduce BEPS incentives by extending taxation at source while avoiding double taxation }\end{array}$} \\
\hline $\begin{array}{l}\text { Bilateral Interest and Royalty } \\
\text { Deduction Limitations }\end{array}$ & $\begin{array}{l}\text { Inverted Tax Credit } \\
\text { (Lodin }(2011 / 2013))\end{array}$ & $\begin{array}{l}\text { Withholding Taxes on all Interest } \\
\text { and Royalty Payments }\end{array}$ & $\begin{array}{l}\text { Withholding Taxes as an } \\
\text { Anti-Avoidance Regulation }\end{array}$ \\
\hline $\begin{array}{l}\text { Source country: } \\
\text { - Limitation of interest and royalty } \\
\text { deductibility outside a safe haven } \\
\text { Residence country: } \\
\text { - Reclassification of non-deductible } \\
\text { interest and royalty payments as } \\
\text { dividends } \\
\text { - Dividends are either tax-exempt or } \\
\text { underlying taxes are credited }\end{array}$ & $\begin{array}{l}\text { Source country: } \\
\text { - Interest and royalty payments not } \\
\text { deductible for tax purposes } \\
\text { - Tax credit based on the tax rate } \\
\text { applicable to the income at the level of } \\
\text { the recipient (intra-group payments) or } \\
\text { the source country's corporate tax rate } \\
\text { (payments to unrelated parties) } \\
\text { Residence country: } \\
\text { - Unlimited right to tax }\end{array}$ & $\begin{array}{l}\text { Source country: } \\
\text { - Withholding tax on all interest and } \\
\text { royalty payments } \\
\text { Residence country: } \\
\text { - Foreign withholding taxes are credited } \\
\text { or refunded }\end{array}$ & $\begin{array}{l}\text { Source country: } \\
\text { - Withholding tax on all interest and } \\
\text { royalty payments } \\
\text { - Upon application reduction of } \\
\text { withholding tax according to a tax } \\
\text { treaty or the EU IRD or if a defined } \\
\text { minimum level of taxation is proven } \\
\text { Residence country (tax haven): } \\
\text { - No or very low taxation }\end{array}$ \\
\hline $\begin{array}{l}\text { Scope: } \\
\text { - Secures taxation at source in the case } \\
\text { of excessive debt financing and } \\
\text { licensing } \\
\text { - Anti-avoidance measure }\end{array}$ & $\begin{array}{l}\text { Scope: } \\
\text { - Completely eliminates profit shifting } \\
\text { incentives } \\
\text { - Secures taxation at source only if } \\
\text { foreign tax rate is lower }\end{array}$ & $\begin{array}{l}\text { Scope: } \\
\text { - Generally secures taxation at source }\end{array}$ & $\begin{array}{l}\text { Scope: } \\
\text { - Secures taxation at source in the case } \\
\text { of profit shifting to tax havens } \\
\text { - Ensures a minimum taxation either in } \\
\text { the residence or the source country } \\
\text { - Anti-avoidance measure }\end{array}$ \\
\hline $\begin{array}{l}\text { Tax revenue consequences: } \\
\text { - Reallocation of taxing rights for } \\
\text { interest and royalty payments outside } \\
\text { a defined safe haven }\end{array}$ & $\begin{array}{l}\text { Tax revenue consequences: } \\
\text { - Residence country: no changes } \\
\text { - Reallocation of taxing rights only if } \\
\text { WHT is replaced }\end{array}$ & $\begin{array}{l}\text { Tax revenue consequences: } \\
\text { - Reallocation of taxing rights from } \\
\text { residence to source countries }\end{array}$ & $\begin{array}{l}\text { Tax revenue consequences: } \\
\cdot \text { No reallocation of taxing rights }\end{array}$ \\
\hline $\begin{array}{l}\text { Effect on investment: } \\
\text { - Source country tax on the non- } \\
\text { deductible payments is definite } \\
\text { - Might have a negative effect on } \\
\text { investment, especially for high-tax } \\
\text { countries }\end{array}$ & $\begin{array}{l}\text { Effect on investment: } \\
\text { - Source country tax is minimum tax for } \\
\text { interest and royalty payments } \\
\text { - Might have a considerable negative } \\
\text { effect on investment, especially for } \\
\text { high-tax countries }\end{array}$ & $\begin{array}{l}\text { Effect on investment: } \\
\text { - Withholding tax is not definite } \\
\text { - No impact on investment decisions }\end{array}$ & $\begin{array}{l}\text { Effect on investment: } \\
\text { - Withholding tax is minimum tax } \\
\text { - No impact on investment decisions if } \\
\text { applied at a uniform rate at the } \\
\text { international level }\end{array}$ \\
\hline $\begin{array}{l}\text { Required level of cooperation: } \\
\cdot \text { Multilateral cooperation necessary }\end{array}$ & $\begin{array}{l}\text { Required level of cooperation: } \\
\text { - Can be introduced unilaterally } \\
\text { respect to interest payments if applied } \\
\text { by a few countries only } \\
\text { - Higher negative effect on investment } \\
\text { if applied by a few countries only }\end{array}$ & $\begin{array}{l}\text { Required level of cooperation: } \\
\text { - Multilateral cooperation necessary }\end{array}$ & $\begin{array}{l}\text { Required level of cooperation: } \\
\text { - Can be introduced unilaterally } \\
\text { - With respect to interest payments, } \\
\text { withholding tax may be avoided if } \\
\text { applied by a few countries only }\end{array}$ \\
\hline
\end{tabular}

\subsection{Bilaterally limiting interest and royalty deductibility}

Many OECD countries extend interest taxation at source by unilateral thin capitalization or earnings stripping rules. These rules disallow the deduction of interest payments in cases where a company exceeds a given threshold (see Figure 1). In principle, similar rules could also be introduced for royalty payments. However, to avoid double taxation, the residence country should reclassify the non-deductible payments as dividends. These dividends would then have to be either exempt from tax in the residence country or qualify for a credit of the 
underlying source tax. ${ }^{36}$ This reform option requires multilateral cooperation and countries would have to adapt both their national tax law and bilateral tax treaties accordingly.

Bilaterally limiting the deductibility of interest and royalty income based on a fixed ratio (e.g. debt-to-equity) aims at securing the source country's tax base in case of high levels of debt financing and licensing. This measure only limits profit shifting above a defined acceptable level and basically constitutes an anti-avoidance measure. Part of the taxing rights would be reallocated from the residence to the source country and the source country would gain while the residence country would lose some tax revenue.

An important side effect of this reform option is that the source tax becomes definite for the non-deductible part of the interest or royalty payment. Therefore, the nominal tax rate in the source country will become more relevant for investment decisions. In high-tax countries, the tax burden on investment made by affected companies would increase. This is the desired effect of anti-tax-avoidance measures. But the level of these firms' investment may decline.

\subsection{Replacing the deductibility of payments by an inverted tax credit}

Another possible way to ensure an effective taxation of cross-border interest and royalty payments has been brought forward by Lodin. ${ }^{37}$ According to his suggestion, the deduction of interest and royalty payments should be disallowed and an inverted tax credit should be granted instead. The amount of the inverted tax credit should depend on whether the lender or licenser is a related or a third party. If the interest or royalties were paid to an external lender or licenser (foreign or domestic), the inverted tax credit would be based on the source country's corporate tax rate. If the lender or licenser was an associated or group company or if the loan was guaranteed for by a related party, the inverted tax credit would be based on the tax rate applied to the income at the level of the receiving company. However, the tax credit rate would be limited to the domestic income tax rate. In case of losses, the inverted tax credit could be carried forward.

Table 1 illustrates the tax burden effects of this proposal. The example assumes profits of 100 and interest or royalty payments of 100 that are paid to a group company resident in either a low-tax country (corporate tax rate of $10 \%$ ) or a high-tax country (corporate tax rate of $40 \%$ ). The tax rate in the source country is $30 \%$.

\footnotetext{
${ }^{36}$ Expenses related to royalty or interest income should nevertheless be deductible.

${ }^{37}$ For the proposal for interest payments, see Lodin (2011); for the proposal for royalty payments, see Lodin (2013).
} 
Table 1: Tax burden effect of the proposed inverted tax credit

\begin{tabular}{lrr}
\hline Nominal corporate tax rate in residence country & $\mathbf{1 0} \%$ & $\mathbf{4 0} \mathbf{0}$ \\
\hline Profits before interest/royalty payment & 100 & 100 \\
\hline Interest/royalty payment & 100 & 100 \\
\hline Taxable income & 100 & 100 \\
\hline Tax on profits in source country (30\%) & 30 & 30 \\
\hline Tax credit based on interest/license cost & 10 & 30 \\
\hline Final tax liability in source country & $\mathbf{2 0}$ & $\mathbf{0}$ \\
\hline Interest/royalty income in residence country & 100 & 100 \\
\hline Tax in residence country (10\%) & $\mathbf{1 0}$ & $\mathbf{4 0}$ \\
\hline Total taxes & $\mathbf{3 0}$ & $\mathbf{4 0}$ \\
\hline
\end{tabular}

The calculations in Table 1 show that, under the proposed inverted tax credit system, intragroup interest and royalty payments are always at least subject to the source country's corporate income tax rate but double taxation of the income is avoided. If the recipient is a third party, a domestic group company or a group company resident in a country with the same or a higher tax rate relative to the source country, the tax treatment of the interest or royalty in the source country will equal the tax treatment under the current system, where interest and royalty payments are tax deductible. The tax treatment differs from the current system if interest and royalties are paid to a group company resident in a low-tax country. In this case, the overall tax burden of the multinational group increases compared to the current situation. ${ }^{38}$

Unlike the other reform options considered in this paper, the inverted tax credit completely removes opportunities for intra-group profit shifting via interest and royalties and ensures that purely domestic groups are not put at a disadvantage compared to multinational companies. Generally, this reform option also ensures a corresponding treatment of intra-group interest and royalty payments at the level of the payer and the recipient. ${ }^{39}$ An important difference compared to the first reform option (and the following option) is that the residence country would fully keep its taxing rights and would not lose tax revenue, given that the behavior of firms does not change. The source country will only earn tax revenue from an inverted tax credit on interest and royalty income if the recipient resides in a country with a lower tax rate. In this situation, the source country's tax is the minimum tax. By contrast, the source country will not earn any tax revenue from applying an inverted tax credit in the case of profit shifting

\footnotetext{
${ }^{38}$ See also Lodin (2011), p. 178.

${ }^{39}$ See Lodin (2011), p. 178.
} 
to countries with the same or a higher tax rate. The tax revenue effects are discussed further in Section 6.

Such an inverted tax credit system is likely to be compatible with EU law and double taxation treaties (DTT) ${ }^{40}$ and countries could introduce it unilaterally without subjecting multinationals to double taxation. Hence, this reform option is comparatively easy to implement. It should be noted, however, that introducing the inverted tax credit in one country might be ineffective if other high-tax countries do not apply it. To see this consider again the example in Table 1 but assume that there is a second country with a tax rate of $40 \%$, which does not apply the inverted tax credit. The multinational company may set up a subsidiary in that country and route the payment through this country before passing it on to the low-tax country. In this case, it would receive a $30 \%$ tax credit in the source country and effectively achieve a tax burden of $10 \%$.

It may be possible to prevent this avoidance scheme by making the tax credit conditional on the final beneficiary of the interest and royalty payments. But this requires the final beneficiary to be identifiable. Lodin argues that this is more difficult for interest payments than for royalties. Taking this into account, the credit system may be an effective reform option for royalties only, if applied unilaterally. ${ }^{41}$

A drawback of the proposed inverted tax credit system is that the taxes in the source country become definite. This increases the tax burden on investments in high-tax countries. Hence, the same problem arises as with regulations limiting the deductibility of interest and royalty payments (see Section 5.1), which is that limiting profit shifting opportunities may reduce investment in high-tax countries. An inverted tax credit is yet likely to have a stronger negative impact on real investment in high-tax countries than the first reform option, as due to the lack of a safe haven, the whole interest or royalty payment and not only the non-deductible part is subject to definite source taxation. It is to be expected that the effect on investment would be particularly strong if only a few high-tax countries applied the inverted tax credit and that it would still be relevant if all countries applied it, as long as tax rates are not harmonized.

\footnotetext{
40 See Lodin (2011), pp. 178-179.

41 See Lodin (2013).
} 


\subsection{Extending the use of withholding taxes}

In an earlier paper, we argue that imposing withholding taxes at the international level is a reform option worth discussing within the international community. ${ }^{42}$ Interestingly neither the OECD in its action plan on base erosion and profit shifting ${ }^{43}$ nor the European Commission in its communication ${ }^{44}$ and its recommendation ${ }^{45}$ regarding aggressive tax planning consider the introduction of withholding taxes on interest and royalties.

There are two different options for introducing withholding tax to fight profit shifting via intra-group interest and royalty payments: (1) Generally reintroducing withholding tax on all intra-group interest and royalty payments and (2) Specifically targeting profit shifting to zeroor low-tax countries. In the following, we will describe and discuss these options in detail.

\subsubsection{Generally reintroducing withholding taxes}

First, withholding taxes could be levied on all interest and royalty payments, irrespective of the location of the recipient and the taxation at the level of the receiving company. To avoid double taxation, countries would have to ensure that foreign withholding taxes are credited against the tax liability in the residence country and that excess foreign taxes are refunded. Hence, unlike current country practice, the tax credit should not be limited to the amount paid on royalty income net of expenses but should always be granted in full even if the tax liability is zero. This would guarantee that the often-criticized excess tax credits, which may arise if the withholding tax is levied on the gross payment while taxes in the residence country of the recipient are levied on the net payment, would not occur. Of course, such a general reintroduction of withholding taxes on all intra-group interest and royalty payments requires not only amendments of domestic law but also of tax treaties and, in the case of EU member states, also of the EU Interest and Royalties Directive.

Reintroducing withholding taxes on all interest and royalty payments and crediting or refunding these taxes in the residence country would considerably restrict the taxing rights of residence countries and redistribute tax revenue to source countries. To what extent taxing rights are reallocated will depend on the level of withholding tax. In this respect, the $10 \%$ rate proposed in Art. 11 of the OECD Model Convention on Income and on Capital (OECD Model)

\footnotetext{
42 See Fuest et al. (2013).

43 OECD (2013).

${ }^{44}$ European Commission (2012a).

45 European Commission (2012b).
} 
could serve as a reasonable benchmark. In section 6 we will discuss the tax revenue redistribution implied by this reform for royalty payments for a selected group of countries.

An important advantage of refundable withholding taxes compared to the two reform options presented in Sections 5.1 and 5.2 is that the taxation at source would not be definite and thus not be relevant for investment decisions. Put differently, if the refunding system is working, this reform option would not introduce additional investment distortions.

\subsubsection{Levying withholding taxes as an anti-avoidance regulation}

Alternatively, countries could levy withholding taxes as an anti-avoidance regulation, which would only target interest and royalty payments to certain tax havens. To this end, countries should implement regulations in domestic law that provide for levying withholding tax. Such a withholding tax would then be reduced according to a tax treaty or the EU Interest and Royalties Directive upon application from the recipient. Local tax authorities, however, could deny any reduction of the withholding tax on interest and royalty payments to a third NonTreaty country that taxes this income below an acceptable level. There are several examples, which provide some guidance for what an acceptable level could be. For instance, in the context of the EU Common Consolidated Corporate Tax Base (CCCTB) proposal, the threshold is $40 \%$ of the average tax rate in the EU. ${ }^{46}$ This level of acceptable taxation, which is comparable to the already mentioned $10 \%$ rate in Art. 11 of the OECD Model, also serves as an adequate benchmark for an appropriate level of withholding tax. The procedure of claiming tax credit requires a disclosure of the recipient entity and country, which enables tax authorities to efficiently control interest and royalty flows to low-tax countries and tax havens. Therefore, levying withholding taxes in domestic law and granting relief only upon application seems to be a better solution than GAAR. Some countries, such as Croatia, the Czech Republic, Portugal and Denmark, already operate similar anti-avoidance regulations. ${ }^{47}$

This reform option does not primarily aim at extending source taxation but at ensuring a minimum taxation of royalty and interest income either in the source or in the residence country. Different to a general levy of withholding taxes, a withholding tax targeted at payments to tax havens could be introduced unilaterally and no changes to current treaty law and the EU Interest and Royalties Directive would be necessary. However, comparable to the inverted tax

\footnotetext{
${ }^{46}$ European Commission (2011), Article 81, p. 46.

${ }^{47}$ See Section 3.
} 
credit system, countries would have to be able to identify the final beneficiary of interest and royalty payments to apply a withholding tax on payments to tax havens effectively as long as some treaty countries do not apply a similar rule. Otherwise multinationals will be able to circumvent the anti-avoidance regulation by shifting profits via intermediate group members in treaty or EU member states that do not collect withholding taxes. As already mentioned in Section 5.2, identifying the final beneficiary of interest payments may be very difficult and hence levying withholding taxes on payments to tax havens may not be effective, if applied by a few countries only.

In addition, countries have to be aware that such an anti-avoidance rule would not target profit shifting to EU member states and treaty states that undercut the defined acceptable level of taxation of interest and royalty income due to an IP Box regime, for example. To ensure an effective taxation in these cases as well, countries would have to agree on a minimum level of residence taxation of interest and royalties within the EU and in treaty states. Alternatively, an implementation of respective anti-avoidance rules within the EU Interest and Royalties Directive and tax treaties would be necessary, allowing countries to levy withholding tax if the income is not effectively taxed at the level of the recipient. ${ }^{48}$

If tax haven countries do not cooperate, the withholding tax will become definite. However, due to the low rate and the limited application of this rule, potential negative effects on investment should be rather small, especially if applied by several countries.

\footnotetext{
${ }^{48}$ The anti-avoidance rule in Art. 5 of the EU Interest and Royalties Directive, which allows the levying of withholding taxes in the case of fraud and abuse, is insofar not sufficient.
} 


\section{Cross-border royalty and license fee flows and resulting tax revenue effects of selected reform options}

The OECD.Stat database provides balance of payments data on trade in services by partner country for 34 OECD member countries as well as for Hong Kong and Russia. ${ }^{49}$ In a subset of this dataset, aggregate country level data on cross-border royalty and license fee payments and receipts is available for all these countries. Moreover, most countries publish royalty and license fee flow data disaggregated by partner country. In the following, we will present some stylized facts derived from this data and, in particular, use this data to estimate the tax revenue arising from cross-border royalty and license fee flows under the current tax system and compare it to the presumable tax revenue resulting from two of the reform options proposed in Chapter 5.

\subsection{Stylized facts on cross-border royalties and license fee flows}

The time period for which royalty and license fee flow data is available in OECD.Stat differs from country to country. For most countries, aggregate country level data is published for the years $1996-2012 .^{50}$ In the following, we focus on this time span. Graph 1 depicts the royalty and license fee receipts and payments of all countries that at least once during the years 19962012 have ranked among the top five recipient and top five payer countries, respectively.

In all years of the time period observed, the value of royalty income of the U.S. was always a multiple of the value of royalty income of any other country. Other large economies, such as the United Kingdom, Japan, Germany and France, followed behind as the other top recipients of royalties and license fees. Some smaller economies like the Netherlands and Switzerland also ranked among the top five royalty income recipients in the last years. All top recipient countries exhibit an overall increase in royalty inflows over the years 1996-2012. In some countries, royalty income dropped in the years around the global financial crisis of 20072008. While in the U.S. and in Japan, this drop was followed by a stark increase in royalty income, the downward tendency in the United Kingdom, France and Germany continued until 2012.

\footnotetext{
49 OECD (2014).

${ }^{50}$ For 2013, countries have only reported a provisional value so far.
} 
Graph 1: Development of royalty in- and outflows 1996-2012: Top 5 recipients and payers

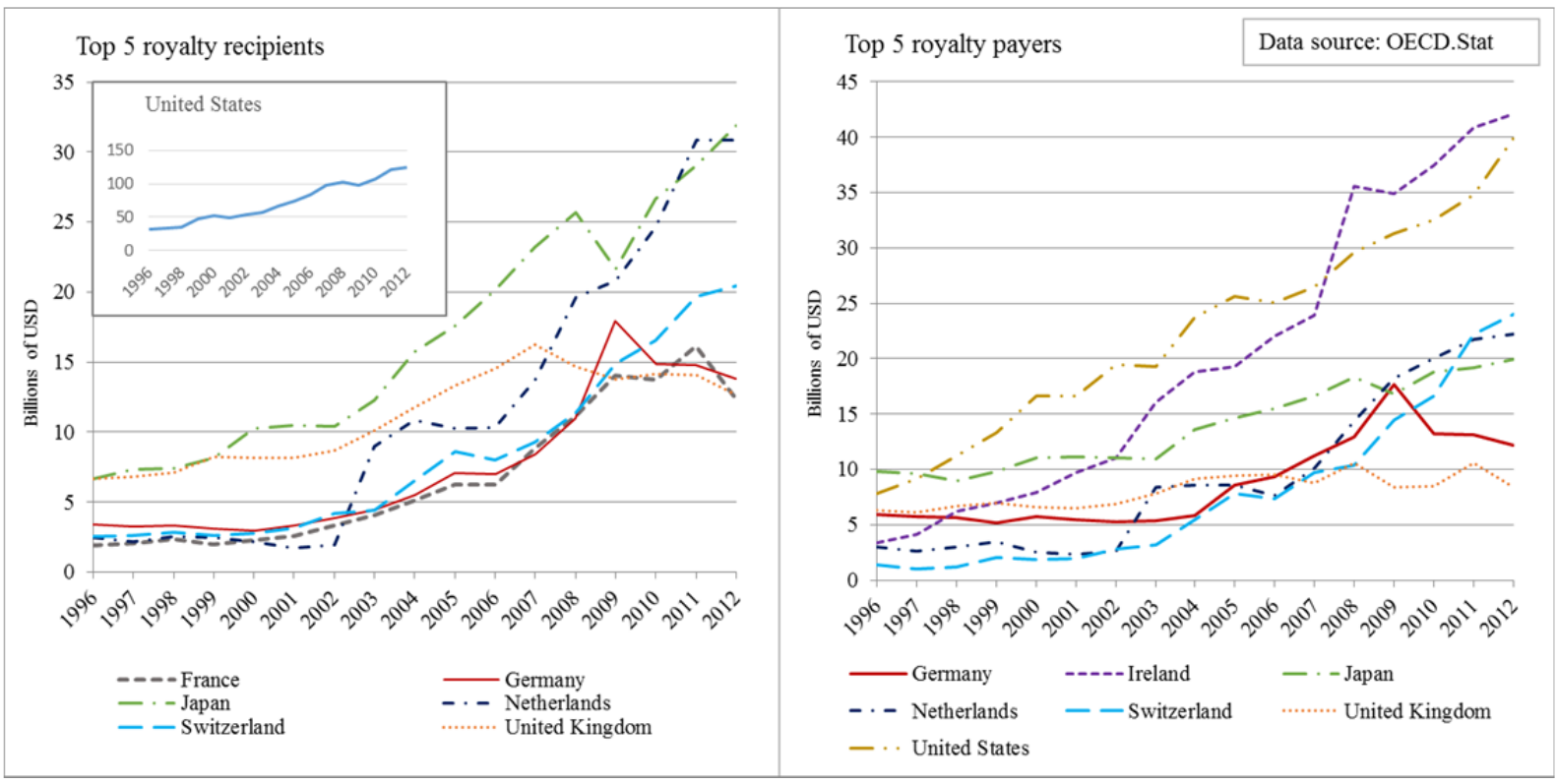

It is interesting to compare the OECD.Stat data on royalties and license fees income to data on the number of granted patents and utility models and registered trademarks and industrial designs by the applicant's country of origin published by WIPO. ${ }^{51}$ There is a positive correlation between the number of intellectual property rights owned by residents of a country and royalty inflows to that country. However, the difference between the number of intellectual property rights owned by the U.S. and the other major IP owner countries is notably smaller than the difference in royalty income received, suggesting that immaterial assets owned by U.S. residents are more valuable or more frequently licensed across borders. Along the same lines, some countries like Germany, the Republic of Korea and Italy in all observed years ranked higher than, for example, the Netherlands in terms of immaterial assets held but received less royalties and license fee income in the years 2003 to 2012.

With respect to royalty and license fee payments made to other countries, the U.S. ranked highest until 2008, when it was overtaken by Ireland. While especially royalty outflows of the U.S., Ireland, the Netherlands and Switzerland have ascended steeply over time, a more gentle increase in royalty payments occurred in France, Japan and the United Kingdom. Royalty and license fee outflows of Germany also constantly increased until 2009 but, different to the payments of the other top payer countries, have considerably decreased afterwards. This trend may have been supported by the reduction of the German corporate tax rate in 2008, which

\footnotetext{
${ }^{51}$ See WIPO (2014).
} 
made it less attractive to reduce the tax base in Germany by shifting profits via royalty payments to countries with a lower tax rate.

Except for France and Ireland, all countries that ranked amongst the top five recipients of royalties and license fees in at least one year during 1996-2012 also ranked amongst the top five payers of royalties and license fees in one or more of those years. Unsurprisingly, countries like the U.S., Japan, the United Kingdom, Germany and France rank among the economies with the largest border crossing royalty flows. The high overall royalties and license fee flows from and to the Netherlands, Switzerland and Ireland are more surprising; In this respect, it is natural to argue that tax planning may play an important role.

In the Netherlands, for example, the general corporate income tax rate had gradually been reduced starting from 2005. In addition, in 2007, the Netherlands introduced an IP Box regime, under which certain royalty income is subject to an effective tax rate of only $5 \%$. These measures may explain the particularly steep increase in royalty income starting from 2006. Switzerland also reduced its general corporate tax rate during the years observed and offered preferential tax regimes for holding and mixed companies in all years, considerably reducing the effective tax rate of IP-Holding companies. Ireland is a typical low-tax country, which since 2003 applies a corporate tax rate for active trade income of only 12,5\%. Under certain conditions, also IP-Holding companies qualify for this low tax rate. In addition, Ireland had offered a patent income exemption regime until 2010, under which certain patent income was fully exempt from taxation cropped to a certain amount per annum. ${ }^{52}$ Thus, in the observed years all three countries offered tax systems for royalty income, which made it attractive to shift profits via royalty payments from high-tax countries to these countries.

One reason for the high value of royalties and license fee payments flowing from the Netherlands and Switzerland to other countries could be that these countries did not levy withholding taxes on royalties in any of the observed years. The lack of withholding taxes on royalties makes it attractive to channel royalty payments from EU member states, to which the EU Interest and Royalties Directive applies, via those countries to third countries, in particular tax havens. For Switzerland, the OECD.Stat database only includes data on the total receipts and payments of royalties and license fees but the Netherlands and Ireland provide royalty flow data disaggregated by partner country. This data supports anecdotal evidence that some U.S.

\footnotetext{
${ }^{52}$ See Kessler/Eicke (2008), p. 846.
} 
based multinationals are channeling royalties free of withholding tax from Ireland via the Netherlands to Bermuda using a tax model called "Double Irish Dutch Sandwich”. ${ }^{3}$ The OECD.Stat data for Ireland shows that, on average, 23\% of all royalty outflows during the years 2004-2010 were attributable to payments to the Netherlands. For the other years, no data is available. According to the data reported by the Netherlands, the country received $50 \%$ of all royalties and license fees from Ireland in 2011. In 2008, the share was 44\% and from 2004 to 2007, it ranged between $17 \%$ and $19 \%$. For the other years, the data is not available. Royalty payments from the Netherlands to Bermuda are not reported for any of the years 1996-2012. However, for the years 2006 and 2007 the data shows that payments from the Netherlands to Non-OECD countries made up 42\% and 26\% of the overall royalty payments, respectively and only a share of $7 \%$ and $8 \%$ of these payments is reported by partner country (including payments to China, Hong Kong, India, Russia, and South Africa). Thus, a considerable share of overall royalties and license fee payments could have been rendered to Bermuda or other tax havens.

Moreover, the data for Ireland shows that from 2007 to 2011, on average, 17\% of all royalties were paid to Luxembourg. From 2008, when Luxembourg introduced an attractive IP Box regime, payments from Ireland to Luxembourg have shown a rising tendency. During the same period, the share of Ireland's payments to the U.S. constantly decreased but, on average, still accounted for 34\% of overall payments. For the U.S., the Bureau of Economic Analysis (BEA) publishes more detailed data on royalty flows by partner country, separately showing royalty flows from and to affiliates and non-affiliates and distinguishing between different royalty types. ${ }^{54}$ The data reveals that from 2006 to 2012 almost 100\% of all payments received from Ireland were attributable to payments from affiliates to their U.S. parent companies, suggesting that licensing IP from U.S. parent companies to Irish affiliates offers tax benefits. This, however, presupposes that the low-taxed profits arising from the exploitation of the intangibles at the level of the Irish company are considerably higher than the royalty payments to the U.S. ${ }^{55}$

\footnotetext{
53 See Kleinbard (2011); Sandell (2012); Fuest et al. (2013).

54 BEA (2014).

55 See also Mutti/Grubert (2009).
} 


\subsection{Tax revenue estimation: Sample selection and underlying assumptions}

What are the tax revenue consequences of the different reform options? To shed some light on this issue, we provide a rough estimate of the tax revenue gains and losses for different countries using the OECD.Stat data on royalties and license fee flows between countries, discussed in Section 6.1. Mainly for reasons of data availability we focus on two of the reform options under consideration, namely the inverted tax credit and the general reintroduction of withholding taxes on cross-border royalty payments (see Section 5).

We compare the tax revenue arising from cross-border royalties and license fee payments under the four following scenarios:

1. The status quo

2. The reform option "generally reintroducing withholding taxes on royalties" which implies that all OECD and EU member states agree to increase their withholding tax rate on all royalties and license fee payments to 10\%. OECD and EU member states that already levy higher withholding taxes on royalty payments to certain countries would keep those higher rates.

3. The reform option "implementing an inverted tax credit system" as proposed by Lodin (see Section 5), assuming that existing withholding taxes remain in place.

4. The reform option "implementing an inverted tax credit system" as proposed by Lodin (see Section 5), assuming that withholding taxes on royalty payments are replaced in all OECD and EU member states. ${ }^{56}$

In order to account for variation in the royalty and license fee data, we calculate the tax revenue that would have resulted from the two reform options as well as the actual tax revenue under the status quo for the years 2006-2012. ${ }^{57}$ To avoid distortions, we only include those countries in our calculations for which at least $90 \%$ of both royalty and license fee inflows and outflows are published on a per country basis in all of these years. This constraint reduces the sample to 12 countries. As the sources of data collection underlying the OECD.Stat data differ from country to country (surveys, compulsory reporting), the value of the royalty and license fee payments reported in one country usually differs from the respective value of roy-

\footnotetext{
${ }^{56}$ Here, we consider both the case that only withholding taxes on intra-group royalties are abolished and the case that all withholding taxes are replaced.

${ }^{57}$ For the Republic of Korea, data disaggregated by partner country was not available for 2012 . Thus, we restricted our calculations to the years 2006-2011 here.
} 
alty and license fee receipts of the partner country. We use the data reported by each country to calculate the tax revenue effects for this country.

The tax revenue arising from cross-border royalty payments under the status quo is determined by

$T_{j}=\sum_{i \neq j}\left[s_{j i} R_{j i}\right]+\sum_{i \neq j}\left[t_{j} R_{i j}\right]-\sum_{i \neq j}\left[\min \left(t_{j}, s_{i j}\right) R_{i j}\right]$

where $s_{j i}$ denotes the withholding tax rate on payments from country $j$ to country $i, R_{j i}$ is the total value of royalty payments from country $\mathrm{j}$ to country $\mathrm{i}, \mathrm{t}_{\mathrm{j}}$ denotes the statutory profit tax rate of country $\mathrm{j}$, $\mathrm{s}_{\mathrm{ij}}$ stands for the withholding tax rate on payments from country i to country $\mathrm{j}$ and $\mathrm{R}_{\mathrm{ij}}$ is the total value of royalty payments from country $\mathrm{i}$ to country $\mathrm{j}$.

Under the status quo, countries collect withholding tax revenue on royalty outflows to certain countries (first term on the right hand side of (1)). In addition, tax revenue is earned from levying residence-based taxes on royalties received from abroad (second term on the right hand side of (1)). This tax revenue is reduced if foreign withholding taxes are credited (third term on the right hand side of (1)). Two countries in our sample, the Czech Republic and France, only credit foreign withholding taxes on royalties if a tax treaty exists between the residence country of the royalty payer and the country of the recipient. Otherwise, the foreign taxes can only be deducted from the domestic tax base. To account for this, in our calculations for the Czech Republic and France, the third term in (1) is replaced by $t_{j} s_{i j} R_{i j}$ for all partner countries $\mathrm{i}$ that are no double taxation treaty partners of the Czech Republic and France, respectively. One country, the Slovak Republic, does not grant any relief for foreign withholding taxes if no tax treaty with the residence country of the payer exists. We take that into account as well.

For the calculation of the withholding tax balance under the status quo $s_{j i}$ and $s_{i j}$ are set to the lower of the applicable domestic and treaty withholding tax rate. The domestic and treaty withholding tax rates are taken from the Ernst \& Young Worldwide Corporate Tax Guides for the years 2006-2012. ${ }^{58}$

As discussed in Section 5, the reform option of levying withholding taxes of $10 \%$ in all OECD and EU member states requires that countries fully credit or even refund all foreign

\footnotetext{
${ }^{58}$ Ernst \& Young (2006-2012).
} 
withholding taxes. Thus, the tax revenue arising from levying and crediting withholding taxes under the reform option is given by

$T_{j}=\sum_{i \neq j}\left[\theta_{j i} R_{j i}\right]+\sum_{i \neq j}\left[t_{j} R_{i j}\right]-\sum_{i \neq j}\left[\theta_{i j} R_{i j}\right]$

For the calculation of the withholding tax revenue and withholding tax credit under the reform option, $\theta_{j i}$ and $\theta_{i j}$ are set to the higher of $10 \%$ and the minimum of the applicable domestic and treaty withholding tax rate under the status quo for all royalty payments made by OECD and EU member states, irrespective of the partner country. For all $R_{i j}$ where $i$ is a Non-OECD and Non-EU member state $\theta_{i j}$ is set to the lower of the applicable domestic and treaty withholding tax rate under the status quo. As the term $t_{j} R_{i j}$ is the same under the status quo and under the reform option of levying withholding taxes at a minimum rate of $10 \%$ in all OECD and EU member states, the change in tax revenue is given by

$\Delta T_{j}^{W H}=S_{j}^{W H}-S_{j}^{S Q}$

where

$S_{j}^{S Q}=\sum_{i \neq j}\left[s_{j i} R_{j i}\right]-\sum_{i \neq j}\left[\min \left(t_{j}, s_{i j}\right) R_{i j}\right]$

is the balance of withholding tax revenue and credited foreign withholding taxes under the status quo and

$S_{j}^{W H}=\sum_{i \neq j}\left[\theta_{j i} R_{j i}\right]-\sum_{i \neq j}\left[\theta_{i j} R_{i j}\right]$

is the balance under a uniform minimum withholding tax of $10 \%$ with full credits for foreign taxes.

The additional tax revenue arising from implementing an inverted tax credit system for all royalty payments is given by:

$\Delta T_{j}^{I T C 1}=\sum_{i \neq j}\left[\left(t_{j}-\min \left(t_{j}, t_{i}\right)\right) R_{j i}^{I G}\right]$

Under this regime, intra-group royalty payments $\left(R_{j i}^{I G}\right)$ are fully subject to corporate income tax. However, there is a credit, which is equal to the tax payable in the residence country of the recipient as long as it does not exceed the domestic tax. Equation (6) assumes that existing withholding taxes would remain in place. If the inverted tax credit replaces existing withholding taxes on intra-group royalty payments in all countries, the change in tax revenue compared to the status quo would be given by 
$\Delta T_{j}^{I T C 2}=\sum_{i \neq j}\left[\left(t_{j}-\min \left(t_{j}, t_{i}\right)\right) R_{j i}^{I G}\right]-\sum_{i \neq j}\left[s_{j i} R_{j i}^{I G}\right]+\sum_{i \neq j}\left[\min \left(t_{j}, s_{i j}\right) R_{i j}^{I G}\right]$

As we assume that only OECD and EU member states agree to replace existing withholding taxes on intra-group royalties by an inverted tax credit, $R_{i j}^{I G}$ is set to zero for all $\mathrm{i}$ that are no OECD or EU member states.

If countries abolish withholding taxes on all royalties (not only intra-group), $R_{j i}^{I G}$ and $R_{i j}^{I G}$ have to be replaced by $R_{j i}$ and $R_{i j}$ in the second and third term on the right hand side of (7).

A drawback of the OECD.Stat data is that it does not distinguish between corporate and individual royalty payers and recipients and that it does not include information on the share of transactions between affiliates and, generally, the taxation at the level of the recipient. Hence, we make the following assumptions:

1. All royalties are paid for the use of patents. Thus, if a double taxation treaty or a country's domestic tax law provide different rates for different kinds of intangibles, we use the withholding tax rate for patent royalties. This assumption is based on U.S. BEA data (see Section 6.1), which shows that the highest percentage of both U.S. royalty payments and receipts are attributable to industrial processes. ${ }^{59}$ For the U.S., we use the more detailed BEA data for our calculations and apply different withholding tax rates dependent on the reported type of intangible.

2. All royalties and license fees are received by companies subject to corporate taxation. The possible bias from using only corporate income tax rates in our calculations of the withholding tax credit under the status quo should be rather small, as for the vast majority of royalty flows in our calculations foreign withholding taxes are lower than both the personal and the corporate income tax rate. At the level of the recipient, royalties may either be subject to the statutory corporate tax rate ${ }^{60}$ or a reduced tax rate under an IP Box regime. As we do not know the value of royalty payments benefiting from an IP Box regime, we estimate the tax revenue consequences for two scenarios. In the first scenario, we completely ignore IP Box regimes. In the second scenario, we assume that all royalties received by a country offering an IP Box regime qualify for low taxation under this regime. ${ }^{61}$ The real value should be within this range.

\footnotetext{
${ }^{59}$ BEA (2014).

60 The corporate tax rates were taken from KPMG (2014).

${ }^{61}$ The IP Box regime tax rates were taken from Evers et al. (2014).
} 
3. There are no deductible expenses related to the royalty income and the royalty income recipients do not have any losses, which could limit the amount of foreign withholding taxes credited under the status quo. In reality, the withholding tax balance under the status quo is likely to be higher, due to excess tax credits.

According to U.S. BEA data, the share of royalty income of U.S. companies received from foreign affiliates ranged between 62\% to 66\% of all foreign royalty income in the years 2006 to 2012 and the share of royalty payments from U.S. companies to affiliates abroad ranged from $70 \%$ to $73 \%$ during the same period. Therefore, we calculate a range of possible tax balance values for all EU member states in our sample, assuming that a minimum of $50 \%$ and a maximum of $100 \%$ of all royalties and license fee flows between EU member states were made between affiliates and qualified for withholding tax rate reduction under the EU Interest and Royalties Directive. As the inverted tax credit system proposed by Lodin is limited to royalty payments between affiliates, we also calculate a range of possible values of additional tax revenue for this proposal, again assuming that a minimum of $50 \%$ and a maximum of $100 \%$ of all royalty and license fee flows are payments between affiliates. For the U.S., we use the more detailed BEA data on royalty payments to affiliates. However, for all U.S. royalty payments to partner countries for which the BEA does not disclose the share of payments to affiliates, we calculate a range of prospective additional tax revenue (50\%-100\%).

In all calculations, we abstract from behavioral responses of taxpayers.

\subsection{Tax revenue estimation: The results}

\subsubsection{Introducing a minimum withholding tax of $10 \%$ in the OECD and the EU}

Graph 2 illustrates the balance of royalties and license fee receipts minus payments in 2012 for all countries reporting in OECD.Stat. It shows that the U.S., Japan and the Netherlands were the top net recipients while Ireland, the Republic of Korea and Switzerland were the top net payers of royalties and license fees in 2012. With respect to possible tax revenue consequences of a broader levy of withholding taxes one may infer from Graph 1 that the top net recipient countries are likely to lose from a reintroduction of withholding tax on royalty payments in all OECD and EU member states, while the top net payer countries should win from this reform option. 
Graph 2: Royalties and license fee balance (receipts-payments) of reporting OECD countries in 2012

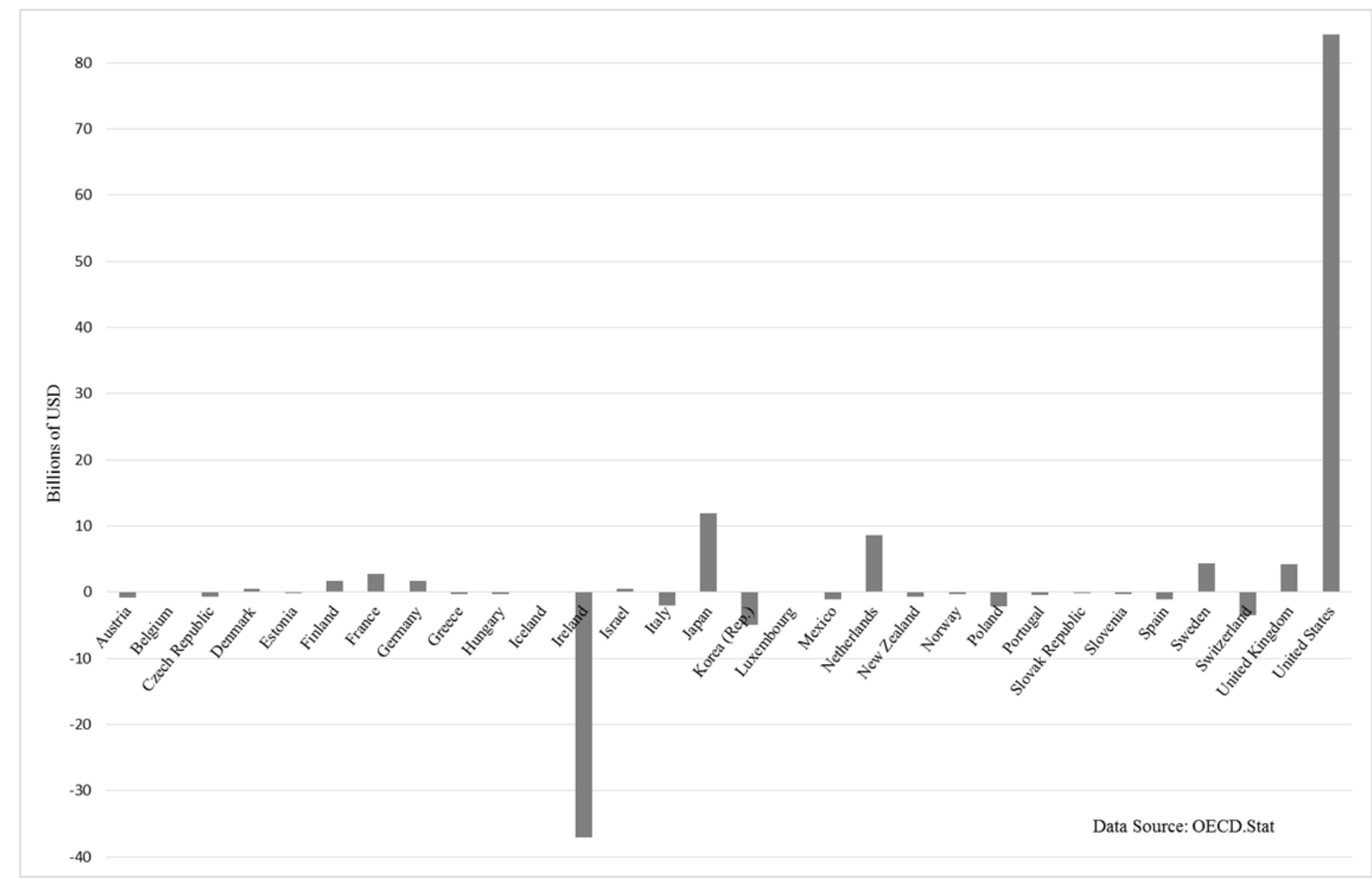

Table 2 presents our tax revenue estimation results for generally reintroducing withholding tax on royalties at a minimum rate of $10 \%$ in all OECD and EU member states under the assumption that $100 \%$ of the royalty flows are intra-group payments and that all royalties qualify for low taxation under an IP Box regime, where available. The values for the other scenarios described in Section 6.2 are presented in Table 3 in the appendix. 
Table 2: Net tax revenue from WHT under the status quo and a minimum WHT of $10 \%$ in all OECD and EU member states: $100 \%$ intra-group payments, IP Boxes considered

\begin{tabular}{|c|c|c|c|c|c|c|c|c|c|}
\hline & Status quo & $\begin{array}{l}\text { WHT } 10 \% \\
\text { OECD + EU }\end{array}$ & Change & Status quo & $\begin{array}{r}\text { WHT } 10 \% \\
\text { OECD + EU }\end{array}$ & Change & Status quo & $\begin{array}{l}\text { WHT } 10 \% \\
\text { OECD + EU }\end{array}$ & Change \\
\hline \multirow[t]{2}{*}{$\begin{array}{l}\text { Millions } \\
\text { of USD }\end{array}$} & $\begin{array}{l}\text { WHT Rev. - } \\
\text { WHT Credit }\end{array}$ & $\begin{array}{l}\text { WHT Rev. - } \\
\text { WHT Credit }\end{array}$ & $\Delta$ Balance & $\begin{array}{l}\text { WHT Rev. - } \\
\text { WHT Credit }\end{array}$ & $\begin{array}{l}\text { WHT Rev. - } \\
\text { WHT Credit }\end{array}$ & $\Delta$ Balance & $\begin{array}{l}\text { WHT Rev. - } \\
\text { WHT Credit }\end{array}$ & $\begin{array}{l}\text { WHT Rev. - } \\
\text { WHT Credit }\end{array}$ & $\Delta$ Balance \\
\hline & AT & & & FR & & & KR & & \\
\hline 2006 & -5 & 80 & 84 & -147 & -233 & -86 & 370 & 369 & -2 \\
\hline 2007 & -8 & 79 & 87 & -223 & -323 & -100 & 437 & 436 & -1 \\
\hline 2008 & -9 & 78 & 87 & -284 & -480 & -197 & 443 & 442 & 0 \\
\hline 2009 & -9 & 60 & 69 & -130 & -386 & -256 & 530 & 529 & -1 \\
\hline 2010 & -9 & 71 & 80 & -139 & -285 & -146 & 755 & 754 & -1 \\
\hline 2011 & -7 & 86 & 93 & -190 & -410 & -219 & 406 & 404 & -2 \\
\hline \multirow[t]{2}{*}{2012} & -7 & 86 & 93 & -137 & -238 & -100 & - & - & - \\
\hline & CZ & & & IL & & & SK & & \\
\hline 2006 & 41 & 51 & 10 & 30 & 14 & -15 & -3 & 1 & 3 \\
\hline 2007 & 47 & 65 & 18 & 13 & 2 & -11 & -5 & -4 & 1 \\
\hline 2008 & 55 & 72 & 17 & 27 & 16 & -11 & -3 & 1 & 4 \\
\hline 2009 & 51 & 64 & 13 & -13 & -28 & -15 & 1 & 7 & 6 \\
\hline 2010 & 52 & 67 & 15 & -15 & -29 & -14 & 3 & 8 & 5 \\
\hline 2011 & 25 & 88 & 63 & -24 & -40 & -17 & 4 & 15 & 11 \\
\hline \multirow[t]{2}{*}{2012} & 17 & 61 & 44 & -27 & -49 & -21 & 3 & 13 & 10 \\
\hline & DE & & & IT & & & SW & & \\
\hline 2006 & -105 & 253 & 357 & 7 & 74 & 67 & -125 & -235 & -110 \\
\hline 2007 & -115 & 262 & 377 & 4 & 63 & 59 & -103 & -275 & -172 \\
\hline 2008 & -174 & 215 & 389 & -50 & 355 & 406 & -151 & -268 & -116 \\
\hline 2009 & -216 & 0 & 216 & -117 & 270 & 387 & -52 & -265 & -214 \\
\hline 2010 & -238 & -133 & 106 & -114 & 331 & 444 & -98 & -422 & -324 \\
\hline 2011 & -273 & -117 & 156 & -118 & 286 & 404 & -78 & -402 & -325 \\
\hline \multirow[t]{2}{*}{2012} & -284 & -125 & 159 & -145 & 176 & 321 & -63 & -392 & -329 \\
\hline & DK & & & JP & & & US & & \\
\hline 2006 & -39 & -39 & 0 & -739 & -580 & 159 & -2117 & -5620 & -3504 \\
\hline 2007 & -71 & -59 & 12 & -826 & -792 & 34 & -2375 & -6394 & -4019 \\
\hline 2008 & -112 & -83 & 29 & -987 & -920 & 67 & -2397 & -6633 & -4236 \\
\hline 2009 & -85 & -100 & -16 & -731 & -591 & 140 & -2598 & -6292 & -3695 \\
\hline 2010 & -65 & -32 & 33 & -947 & -953 & -6 & -3900 & -7539 & -3639 \\
\hline 2011 & -88 & -39 & 49 & -1096 & -1165 & -70 & -4507 & -8756 & -4249 \\
\hline 2012 & -66 & -33 & 32 & -1202 & -1377 & -176 & -4520 & -8444 & -3924 \\
\hline
\end{tabular}

Abbreviations:

WHT - Withholding Tax, AT - Austria, CZ - Czech Republic, DE - Germany, DK - Denmark, FR - France, IL - Israel, IT - Italy, JP - Japan, KR - Republic of Korea, SK - Slovak Republic, SW - Sweden, US - United States

Notes:

All numbers are rounded to the nearest million.

Under the reform option of a broad introduction of withholding taxes, all net royalty recipient (payer) countries exhibit a negative (positive) balance of withholding tax income minus withholding tax credit. However, under the status quo, net payers of royalties and license fees do not necessarily exhibit a positive withholding tax balance. From 2006 to 2008, Germany, for example, was a net payer country but still featured a negative balance of withholding tax income minus withholding tax credits granted during these years. The same is true for Italy with respect to the years 2009-2012. 
Most importantly, our results show that a country, which is a net recipient (payer) of royalties and license fees would not necessarily lose (gain) tax revenue if OECD and EU member states agreed to levy withholding taxes on royalties at a minimum rate of $10 \%$. The tax revenue balance of Germany, one of the top net recipient countries, for example, amounted to between -284 Million USD (100\% intra-group payments, see Table 2) and -295 Million USD (50\% intra-group payments, see Table 3) in 2012. Had all OECD and EU member states levied withholding tax of at least $10 \%$ in 2012, the tax loss from levying and crediting withholding taxes would have been only -125 Million USD. As the tax revenue estimates for the other years yield similar results, a broader levy of withholding taxes in all OECD and EU member states is likely to increase Germany's tax revenue.

The reason for this counterintuitive result is the following: Under the status quo, countries levy withholding taxes on payments to some countries only, and they apply different rates. Thus, whether a country loses or wins from a broader levy of withholding taxes does not only depend on the country's net balance in royalties and license fee flows. It also depends on how the reform changes the composition of withholding taxes. Ultimately, it is key whether the resulting increase in withholding tax revenue exceeds the increase in withholding tax credit.

We find similar results for Austria, the Czech Republic and Italy for all years observed. These countries would have earned more tax revenue compared to the status quo if OECD and EU member states had levied withholding tax of at least $10 \%$ on royalty payments during the years 2006-2012. For Denmark and the Slovak Republic, except for the years 2006/2009 and $2007 / 2008$ (50\% intra-group payments) ${ }^{62}$, respectively, the same is true.

France, Israel, Sweden and the U.S., in contrast, would lose tax revenue. Among these countries, the U.S. would by far incur the highest loss. According to our calculations, the balance of withholding tax revenue and withholding tax credit under the reform option would have been -8.444 Million USD compared to -4.520 Million USD under the status quo in 2012. The calculations for the other years yield comparable results. Thus, the tax loss of the U.S. resulting from levying and crediting withholding taxes is likely to almost double if countries agreed to reintroduce withholding taxes on royalties of at least $10 \%$.

For the Republic of Korea, withholding tax revenue under the status quo and under a broader levy of withholding taxes would remain unchanged while the overall amount of withholding

\footnotetext{
${ }^{62}$ See Table 3.
} 
tax credited would increase marginally. Thus, the withholding tax balance of the Republic of Korea should almost stay the same, if countries agreed on a broader levy of withholding taxes. The reason for this is that the double taxation treaties concluded by the Republic of Korea with all its major partner countries already provide for a $10 \%$ withholding tax rate on royalties and license fee payments.

With respect to Japan, our calculations yield an increase in net withholding tax revenue resulting from the reform option compared to the status quo for the years 2006 to 2009 and a decrease for the years 2010-2012. This result is partly driven by the decrease in the value of royalty payments to the U.S. net of royalty receipts from the U.S. that occurred in the years following 2009. With the U.S., Japan has concluded one of its few double taxation treaties that reduces the withholding tax rate on royalties to zero. Thus, an increase of the withholding tax rate on royalty payments from Japan to the U.S. as well as on royalty payments from the U.S. to Japan to $10 \%$ would have resulted in far higher additional tax revenues in the years 2006-2009 then in the years 2010-2012. This shows that the tax revenue effect of reintroducing withholding taxes strongly depends on the withholding tax rates currently levied on royalty flows between major partner countries.

The example of France also illustrates this. The withholding tax balance of France (status quo) increased in the years after 2008 although the value of the balance of royalty inflows to the country minus royalty outflows from the country was comparable in the years 2008, 2009 and 2011 as well as in the years 2007 and 2010. One reason for this is that the withholding tax rates on royalties in the double taxation treaties with the U.S. and Japan were reduced to zero with effect from 2009 and 2008, respectively. As the royalty inflows from both countries exceeded the royalty payments to both countries in all years observed, France gained more from the resulting lapse of foreign withholding tax credits on the royalty inflows than it lost from refraining to levy withholding taxes on the royalty outflows. Reintroducing withholding taxes on royalty flows between France and the U.S. and Japan would reverse the effect.

\subsubsection{Implementing an inverted tax credit system}

In our calculations for the inverted tax credit, we considered two reform options:

1. The inverted tax credit is introduced in addition to existing withholding taxes

2. The inverted tax credit replaces the levy of withholding taxes in all OECD and EU member states. 
Our results under the assumption that $100 \%$ of the royalty flows are intra-group payments and that all royalties qualify for low taxation under an IP Box regime, where available, are presented in Table 4.

Table 4: Tax revenue effect of the inverted tax credit: $100 \%$ intra-group payments, IP Boxes considered

\begin{tabular}{|c|c|c|c|c|c|c|c|c|c|}
\hline & \multicolumn{9}{|c|}{ Inverted Tax Credit } \\
\hline & & $\begin{array}{l}n \text { addition to } \\
\text { WHT }\end{array}$ & $\begin{array}{c}\text { Instead of } \\
\text { WHT }\end{array}$ & & $\begin{array}{c}\text { In addition to } \\
\text { WHT }\end{array}$ & $\begin{array}{c}\text { Instead of } \\
\text { WHT }\end{array}$ & & $\begin{array}{l}n \text { addition to } \\
\text { WHT }\end{array}$ & $\begin{array}{c}\text { Instead of } \\
\text { WHT }\end{array}$ \\
\hline $\begin{array}{l}\text { Millions of } \\
\text { USD }\end{array}$ & & $\Delta$ Status Quo & $\Delta$ Status Quo & & $\Delta$ Status Quo & $\Delta$ Status Quo & & $\Delta$ Status Quo & $\Delta$ Status Quo \\
\hline & AT & & & $\mathbf{F}$ & & & KR & & \\
\hline 2006 & & 9 & 13 & & 5 & 130 & & 34 & -454 \\
\hline 2007 & & 20 & 26 & & 24 & 222 & & 61 & -471 \\
\hline 2008 & & 26 & 34 & & 43 & 284 & & 62 & -533 \\
\hline 2009 & & 23 & 30 & & 87 & 130 & & 49 & -621 \\
\hline 2010 & & 31 & 38 & & 180 & 237 & & 46 & -877 \\
\hline 2011 & & 44 & 48 & & 275 & 344 & & 37 & -568 \\
\hline 2012 & & 47 & 50 & & 239 & 275 & & - & - \\
\hline & CZ & & & II & & & SK & & \\
\hline 2006 & & 12 & -30 & & 25 & -11 & & 1 & 3 \\
\hline 2007 & & 24 & -23 & & 35 & 21 & & 2 & 6 \\
\hline 2008 & & 19 & -36 & & 40 & 12 & & 6 & 10 \\
\hline 2009 & & 16 & -35 & & 11 & 21 & & 3 & 2 \\
\hline 2010 & & 10 & -42 & & 11 & 23 & & 3 & 0 \\
\hline 2011 & & 22 & -3 & & 12 & 32 & & 2 & -2 \\
\hline 2012 & & 18 & -1 & & 16 & 39 & & 2 & -1 \\
\hline & DE & & & I & & & sw & & \\
\hline 2006 & & 573 & 623 & & 128 & 115 & & 17 & 46 \\
\hline 2007 & & 934 & 980 & & 171 & 154 & & 59 & 91 \\
\hline 2008 & & 561 & 639 & & 803 & 713 & & 93 & 118 \\
\hline 2009 & & 1259 & 1366 & & 734 & 726 & & 62 & 79 \\
\hline 2010 & & 746 & 856 & & 806 & 774 & & 71 & 113 \\
\hline 2011 & & 886 & 986 & & 903 & 871 & & 84 & 113 \\
\hline 2012 & & 931 & 1025 & & 796 & 771 & & 131 & 152 \\
\hline & DK & & & J & & & US & & \\
\hline 2006 & & 31 & 59 & & 676 & 686 & & 1409 & 2253 \\
\hline 2007 & & 43 & 96 & & 833 & 810 & & 1900 & 2911 \\
\hline 2008 & & 65 & 146 & & 1099 & 1030 & & 2711 & 3776 \\
\hline 2009 & & 53 & 101 & & 1063 & 912 & & 2909 & 3907 \\
\hline 2010 & & 47 & 89 & & 1239 & 1025 & & 2723 & 4078 \\
\hline 2011 & & 91 & 144 & & 1372 & 1148 & & 3338 & 4831 \\
\hline 2012 & & 80 & 116 & & 1326 & 1127 & & 4005 & 5159 \\
\hline
\end{tabular}

Abbreviations:

WHT - Withholding Tax, AT - Austria, CZ - Czech Republic, DE - Germany, DK - Denmark, FR - France, IL - Israel, IT - Italy, JP - Japan, KR - Republic of Korea, SK - Slovak Republic, SW - Sweden, US - United States

Notes:

All numbers are rounded to the nearest million. "Instead of WHT" implies that all OECD and EU member states replace withholding taxes by an inverted tax credit.

For the alternative scenarios, the tax revenue effects are presented in Table 5.

It shows that the inverted tax credit significantly increases the tax revenue of high-tax countries like e.g. France, Germany, Italy, Japan and the U.S., irrespective of whether or not with- 
holding taxes are replaced. If withholding taxes are not replaced, no country loses tax revenue but the lower a country's tax rate is in comparison to other countries' tax rates the lower is the additional tax revenue earned form the inverted tax credit. The example of Germany illustrates this well. Although royalty outflows from Germany have constantly been growing from 2006-2009, an inverted tax credit system would have resulted in lower additional tax revenue in 2008 and 2009 compared to 2006 and 2007 if IP Box regimes are not considered (see Table 5). This can be explained by the 2008 tax rate cut in Germany. If IP Box regimes are considered (see Table 4), the German tax revenue resulting from an inverted tax credit system would have been highest in 2009 despite the tax rate cut in 2008. One reason for this is that payments to France and the Netherlands, which both offer a low-tax IP Box regime have been considerably higher in 2009 than in any other year observed. Thus, the domestic tax rate as well as the destination of the royalty outflows are key determinants of the tax revenue effect of implementing an inverted tax credit. When comparing the tax revenue resulting from reintroducing withholding taxes (see Table 3) to implementing an inverted tax credit in Germany in the years 2006-2012, it shows that the former is far less dependent on the destination of royalty outflows.

If an inverted tax credit system would replace the levy of withholding taxes, especially lowtax countries that are net payers of royalties and license fees and currently levy withholding tax on royalty payments to some countries, like the Czech Republic, the Republic of Korea, or the Slovak Republic may lose tax revenue. The Republic of Korea, for example, would have earned 568 million USD less compared to the status quo if all OECD and EU member states had replaced levying withholding taxes on intra-group royalties by an inverted tax credit in $2012 .{ }^{63}$

In summary, our tax revenue estimates show that the reallocation of taxing rights caused by a general levy of withholding taxes of $10 \%$ in all OECD and EU member states would lead to a significant redistribution of tax revenues. Interestingly, there is no perfect correlation between net royalty payment flows and revenue gains or losses. Introducing an inverted tax credit system to replace withholding taxes would also lead to a redistribution of tax revenue. If an inverted tax credit was introduced without abolishing the withholding taxes levied under the status quo, it is clear that no country would lose revenue and especially high-tax countries

\footnotetext{
${ }^{63}$ Assuming that $100 \%$ royalty payments were made intra-group and considering IP Box regimes. Table 5 shows that the losses would have been considerable under the other scenarios as well.
} 
would collect more revenue. Clearly, the drawback is that an inverted tax credit would increase the tax burden on investment in high-tax countries, and this may lead firms to invest less or restructure their activities. Our calculations abstract from these behavioral changes.

\section{Conclusions}

In this paper, we have discussed options to fight tax base erosion and profit shifting by extending the taxation of interest income and royalties in the source country. Most countries have introduced limitations on interest deductions during the last two decades, albeit usually on a unilateral basis, so that these measures may easily lead to double taxation of corporate income. Interestingly much less has been done to limit the deductibility of royalties. Instead, many countries have introduced special tax regimes, like IP boxes, to attract royalty income.

As one option for reform, thin capitalization and earnings stripping rules could be introduced by more countries and similar rules could also be applied to intra-group royalties. To avoid double taxation of the interest and royalty income, these regulations need to be modified to reclassify non-deductible interest or royalty payments in the source country as deemed dividends in the residence country of the recipient. The deemed dividends then have to be taxexempt or a tax credit has to be granted. This reform option requires at least bilateral cooperation between countries and secures source countries' tax revenue in cases of what is defined as ‘excessive’ debt financing or an 'excessive' level of royalties. Defining these levels is challenging and controversial, though.

Alternatively, countries could choose broader reform options and change the tax rules for all interest and royalty payments. One option considered in this paper is to introduce a minimum withholding tax on interest and royalty payments in all OECD countries. This would require residence countries to credit or refund the withholding taxes. To achieve this, changes to double taxation treaties and the EU Interest and Royalties Directive are necessary. Moreover, this reform would give rise to a significant redistribution of tax revenue. According to our calculations, the US, the world's largest net recipient of royalty income, would suffer revenue losses of roughly $\$ 4$ bn in 2012, or 5 per cent of net royalty inflows. Surprisingly other net royalty recipients including Germany would benefit from this reform. Clearly, the revenue effects would make it difficult to find agreement. One should also bear in mind that incentives for shifting profits through royalties would not be completely neutralized by a $10 \%$ withholding tax, given that the headline corporate profit tax is often close to $30 \%$. 
A more limited approach is to levy withholding taxes on payments to tax havens only. This type of anti-avoidance regulation solely requires changes to domestic tax law. However, to apply this measure effectively as well as to also tackle profit shifting to EU member states and treaty countries that undercut the acceptable level of taxation, international coordination and consent would be necessary for this reform option as well.

Another reform option we have analyzed is the inverted tax credit proposed by Lodin. ${ }^{64}$ The inverted tax credit is the only presented reform option that completely eliminates profit shifting incentives and ensures that purely domestic companies are not put at a disadvantage compared to multinational firms. In addition, an inverted tax credit system allows strengthening source taxation unilaterally without causing double taxation and it is therefore easy to implement. However, if applied by a few countries only, the inverted tax credit system may be ineffective because companies may route royalties or interest payments through high tax countries who do not apply the tax credit. For interest payments, this is probably impossible but even for royalties this may be challenging.

Moreover, applying an inverted tax credit would increase the tax burden on economic activity, so that investment may decline. This is an important difference to withholding taxes. If they are fully credited in the residence countries, the overall tax burden on investment remains the same. Of course, a country that does introduce the inverted tax credit could use the additional revenue to cut corporate taxes, so that the negative impact on investment can be avoided or reduced. The same is true for additional tax revenue from withholding taxes.

\footnotetext{
${ }^{64}$ See Lodin (2011) and Lodin (2013).
} 


\section{Appendix}

Table 3: Tax revenue from WHT under the status quo and a minimum WHT of $10 \%$ in all OECD and EU member states: all scenarios

\begin{tabular}{|c|c|c|c|c|c|c|c|c|c|c|c|}
\hline \multirow[b]{2}{*}{$\begin{array}{l}\text { Millions of } \\
\text { USD }\end{array}$} & \multicolumn{6}{|c|}{ Status quo } & \multicolumn{3}{|c|}{ WHT $10 \%$ OECD + EU } & \multicolumn{2}{|c|}{ Change } \\
\hline & $\begin{array}{r}\text { WHT Rev. } \\
50 \% \text { IRD }\end{array}$ & $\begin{array}{l}\text { WHT Rev. } \\
100 \% \text { IRD }\end{array}$ & $\begin{array}{r}\text { WHT Credit } \\
50 \% \text { IRD }\end{array}$ & $\begin{array}{l}\text { WHT Credit } \\
100 \% \text { IRD }\end{array}$ & $\begin{array}{l}\text { Balance } \\
50 \% \text { IRD }\end{array}$ & $\begin{array}{r}\text { Balance } \\
100 \% \text { IRD }\end{array}$ & WHT Rev. & WHT Credit & Balance & $\begin{array}{r}\Delta \text { Balance } \\
50 \% \text { IRD }\end{array}$ & $\begin{array}{l}\Delta \text { Balance } \\
100 \% \text { IRD }\end{array}$ \\
\hline \multicolumn{12}{|l|}{ AT } \\
\hline 2006 & 41 & 1 & 9 & 6 & 32 & -5 & 129 & 49 & 80 & 47 & 84 \\
\hline 2007 & 46 & 1 & 13 & 9 & 33 & -8 & 145 & 66 & 79 & 46 & 87 \\
\hline 2008 & 49 & 3 & 19 & 12 & 31 & -9 & 160 & 82 & 78 & 47 & 87 \\
\hline 2009 & 36 & 1 & 16 & 10 & 19 & -9 & 126 & 66 & 60 & 40 & 69 \\
\hline 2010 & 31 & 1 & 13 & 9 & 18 & -9 & 130 & 59 & 71 & 53 & 80 \\
\hline 2011 & 30 & 1 & 13 & 8 & 17 & -7 & 148 & 62 & 86 & 69 & 93 \\
\hline 2012 & 33 & 2 & 15 & 9 & 18 & -7 & 153 & 67 & 86 & 68 & 93 \\
\hline \multicolumn{12}{|l|}{ CZ } \\
\hline 2006 & 42 & 42 & 1 & 0 & 40 & 41 & 55 & 3 & 51 & 11 & 10 \\
\hline 2007 & 48 & 48 & 2 & 1 & 47 & 47 & 68 & 3 & 65 & 18 & 18 \\
\hline 2008 & 56 & 56 & 3 & 2 & 54 & 55 & 77 & 5 & 72 & 18 & 17 \\
\hline 2009 & 57 & 57 & 7 & 6 & 50 & 51 & 73 & 9 & 64 & 14 & 13 \\
\hline 2010 & 59 & 59 & 8 & 7 & 51 & 52 & 77 & 10 & 67 & 16 & 15 \\
\hline 2011 & 54 & 32 & 8 & 7 & 46 & 25 & 99 & 11 & 88 & 42 & 63 \\
\hline 2012 & 44 & 28 & 14 & 11 & 30 & 17 & 81 & 20 & 61 & 31 & 44 \\
\hline \multicolumn{12}{|l|}{ DE } \\
\hline 2006 & 46 & 36 & 148 & 141 & -102 & -105 & 932 & 680 & 253 & 355 & 357 \\
\hline 2007 & 69 & 60 & 181 & 174 & -112 & -115 & 1076 & 814 & 262 & 374 & 377 \\
\hline 2008 & 68 & 57 & 242 & 230 & -175 & -174 & 1291 & 1076 & 215 & 390 & 389 \\
\hline 2009 & 74 & 45 & 270 & 261 & -197 & -216 & 1770 & 1770 & 0 & 197 & 216 \\
\hline 2010 & 70 & 55 & 304 & 293 & -234 & -238 & 1325 & 1458 & -133 & 101 & 106 \\
\hline 2011 & 93 & 72 & 368 & 345 & -275 & -273 & 1315 & 1432 & -117 & 158 & 156 \\
\hline 2012 & 79 & 58 & 374 & 341 & -295 & -284 & 1214 & 1338 & -125 & 170 & 159 \\
\hline \multicolumn{12}{|l|}{ DK } \\
\hline 2006 & 17 & 16 & 56 & 55 & -39 & -39 & 132 & 171 & -39 & 0 & 0 \\
\hline 2007 & 3 & 3 & 75 & 73 & -72 & -71 & 135 & 194 & -59 & 13 & 12 \\
\hline 2008 & 6 & 5 & 120 & 117 & -113 & -112 & 173 & 256 & -83 & 30 & 29 \\
\hline 2009 & 29 & 3 & 102 & 87 & -73 & -85 & 174 & 274 & -100 & -27 & -16 \\
\hline 2010 & 22 & 6 & 82 & 71 & -61 & -65 & 172 & 205 & -32 & 28 & 33 \\
\hline 2011 & 20 & 3 & 106 & 92 & -87 & -88 & 188 & 227 & -39 & 48 & 49 \\
\hline 2012 & 23 & 5 & 87 & 71 & -64 & -66 & 187 & 220 & -33 & 31 & 32 \\
\hline \multicolumn{12}{|l|}{ FR } \\
\hline 2006 & 73 & 57 & $207 / 206$ & $205 / 204$ & $-134 /-133$ & $-148 /-147$ & 328 & 562 & -233 & $-100 /-101$ & $-85 /-86$ \\
\hline 2007 & 121 & 97 & $324 / 323$ & $321 / 320$ & -202 & $-224 /-223$ & 465 & 788 & -323 & -121 & $-99 /-100$ \\
\hline 2008 & 115 & 92 & $380 / 379$ & $377 / 375$ & $-266 /-265$ & $-285 /-284$ & 516 & 996 & -480 & $-215 /-216$ & $-196 /-197$ \\
\hline 2009 & 90 & 37 & $185 / 184$ & $168 / 167$ & $-95 /-94$ & $-131 /-130$ & 898 & 1284 & -386 & $-291 /-293$ & $-255 /-256$ \\
\hline 2010 & 73 & 27 & $181 / 178$ & $168 / 167$ & $-107 /-105$ & $-141 /-139$ & 985 & 1270 & -285 & $-177 /-180$ & $-144 /-146$ \\
\hline 2011 & 95 & 33 & $245 / 242$ & $225 / 224$ & $-150 /-148$ & $-192 /-190$ & 1097 & 1506 & -410 & $-259 /-262$ & $-218 /-219$ \\
\hline 2012 & 75 & 24 & $186 / 184$ & $162 / 161$ & $-111 /-109$ & $-138 /-137$ & 910 & 1148 & -238 & $-126 /-128$ & $-99 /-100$ \\
\hline \multicolumn{12}{|c|}{ - } \\
\hline 2006 & 81 & 81 & 52 & 52 & 30 & 30 & 91 & 77 & 14 & -15 & -15 \\
\hline 2007 & 69 & 69 & 55 & 55 & 13 & 13 & 75 & 72 & 2 & -11 & -11 \\
\hline 2008 & 84 & 84 & 57 & 57 & 27 & 27 & 92 & 76 & 16 & -11 & -11 \\
\hline 2009 & 43 & 43 & 56 & 56 & -13 & -13 & 47 & 75 & -28 & -15 & -15 \\
\hline 2010 & 44 & 44 & 59 & 59 & -15 & -15 & 48 & 77 & -29 & -14 & -14 \\
\hline 2011 & 48 & 48 & 71 & 71 & -24 & -24 & 53 & 93 & -40 & -17 & -17 \\
\hline 2012 & 60 & 60 & 88 & 88 & -27 & -27 & 67 & 115 & -49 & -21 & -21 \\
\hline IT & & & & & & & & & & & \\
\hline 2006 & 90 & 47 & 51 & 40 & 38 & 7 & 182 & 109 & 74 & 36 & 67 \\
\hline 2007 & 76 & 38 & 46 & 34 & 30 & 4 & 165 & 102 & 63 & 32 & 59 \\
\hline 2008 & 341 & 197 & 275 & 247 & 65 & -50 & 772 & 417 & 355 & 290 & 406 \\
\hline 2009 & 293 & 163 & 303 & 280 & -10 & -117 & 669 & 399 & 270 & 280 & 387 \\
\hline 2010 & 273 & 143 & 278 & 256 & -5 & -114 & 711 & 380 & 331 & 336 & 444 \\
\hline 2011 & 259 & 117 & 264 & 235 & -5 & -118 & 697 & 412 & 286 & 291 & 404 \\
\hline 2012 & 223 & 98 & 272 & 243 & -49 & -145 & 603 & 427 & 176 & 225 & 321 \\
\hline JP & & & & & & & & & & & \\
\hline 2006 & 445 & 445 & 1184 & 1184 & -739 & -739 & 1528 & 2108 & -580 & 159 & 159 \\
\hline 2007 & 412 & 412 & 1238 & 1238 & -826 & -826 & 1626 & 2418 & -792 & 34 & 34 \\
\hline 2008 & 443 & 443 & 1430 & 1430 & -987 & -987 & 1757 & 2677 & -920 & 67 & 67 \\
\hline 2009 & 432 & 432 & 1163 & 1163 & -731 & -731 & 1643 & 2234 & -591 & 140 & 140 \\
\hline 2010 & 518 & 518 & 1465 & 1465 & -947 & -947 & 1830 & 2783 & -953 & -6 & -6 \\
\hline 2011 & 525 & 525 & 1620 & 1620 & -1096 & -1096 & 1864 & 3030 & -1165 & -70 & -70 \\
\hline 2012 & 527 & 527 & 1729 & 1729 & -1202 & -1202 & 1939 & 3317 & -1377 & -176 & -176 \\
\hline
\end{tabular}




\begin{tabular}{|c|c|c|c|c|c|c|c|c|c|c|c|}
\hline \multicolumn{12}{|l|}{ KR } \\
\hline 2006 & 596 & 596 & 226 & 226 & 370 & 370 & 596 & 228 & 369 & -2 & -2 \\
\hline 2007 & 655 & 655 & 218 & 218 & 437 & 437 & 655 & 219 & 436 & -1 & -1 \\
\hline 2008 & 719 & 719 & 277 & 277 & 443 & 443 & 719 & 277 & 442 & 0 & 0 \\
\hline 2009 & 917 & 917 & 387 & 387 & 530 & 530 & 917 & 387 & 529 & -1 & -1 \\
\hline 2010 & 1114 & 1114 & 359 & 359 & 755 & 755 & 1114 & 360 & 754 & -1 & -1 \\
\hline 2011 & 916 & 916 & 510 & 510 & 406 & 406 & 916 & 512 & 404 & -2 & -2 \\
\hline \multicolumn{12}{|l|}{ SK } \\
\hline 2006 & 5 & 1 & 5 & 4 & 0 & -3 & 11 & 10 & 1 & 0 & 3 \\
\hline 2007 & 6 & 2 & 8 & 7 & -2 & -5 & 12 & 16 & -4 & -2 & 1 \\
\hline 2008 & 8 & 3 & 7 & 6 & 1 & -3 & 18 & 18 & 1 & -1 & 4 \\
\hline 2009 & 9 & 5 & 5 & 4 & 4 & 1 & 16 & 9 & 7 & 2 & 6 \\
\hline 2010 & 7 & 4 & 1 & 1 & 6 & 3 & 15 & 7 & 8 & 2 & 5 \\
\hline 2011 & 8 & 4 & 0 & 0 & 8 & 4 & 15 & 0 & 15 & 7 & 11 \\
\hline 2012 & 7 & 3 & 0 & 0 & 6 & 3 & 13 & 0 & 13 & 6 & 10 \\
\hline \multicolumn{12}{|l|}{ SW } \\
\hline 2006 & 12 & 11 & 138 & 136 & -126 & -125 & 164 & 399 & -235 & -108 & -110 \\
\hline 2007 & 21 & 19 & 124 & 122 & -103 & -103 & 182 & 457 & -275 & -171 & -172 \\
\hline 2008 & 23 & 22 & 175 & 173 & -152 & -151 & 198 & 465 & -268 & -116 & -116 \\
\hline 2009 & 23 & 21 & 75 & 73 & -51 & -52 & 180 & 446 & -265 & -214 & -214 \\
\hline 2010 & 10 & 6 & 105 & 103 & -94 & -98 & 146 & 568 & -422 & -328 & -324 \\
\hline 2011 & 10 & 8 & 91 & 85 & -82 & -78 & 188 & 590 & -402 & -321 & -325 \\
\hline 2012 & 26 & 23 & 96 & 86 & -70 & -63 & 233 & 625 & -392 & -322 & -329 \\
\hline \multicolumn{12}{|l|}{ US } \\
\hline 2006 & 443 & 443 & 2560 & 2560 & -2117 & -2117 & 2479 & 8100 & -5620 & -3504 & -3504 \\
\hline 2007 & 547 & 547 & 2921 & 2921 & -2375 & -2375 & 2733 & 9127 & -6394 & -4019 & -4019 \\
\hline 2008 & 564 & 564 & 2960 & 2960 & -2397 & -2397 & 2972 & 9605 & -6633 & -4236 & -4236 \\
\hline 2009 & 482 & 482 & 3080 & 3080 & -2598 & -2598 & 3134 & 9426 & -6292 & -3695 & -3695 \\
\hline 2010 & 229 & 229 & 4130 & 4130 & -3900 & -3900 & 3014 & 10553 & -7539 & -3639 & -3639 \\
\hline 2011 & 311 & 311 & 4819 & 4819 & -4507 & -4507 & 3240 & 11996 & -8756 & -4249 & -4249 \\
\hline 2012 & 797 & 797 & 5317 & 5317 & -4520 & -4520 & 4063 & 12507 & -8444 & -3924 & -3924 \\
\hline
\end{tabular}

Abbreviations:

WHT - Withholding Tax, IRD - Interest and Royalties Directive, AT - Austria, CZ - Czech Republic, DE Germany, DK - Denmark, FR - France, IL - Israel, IT - Italy, JP - Japan, KR - Republic of Korea, SK - Slovak Republic, SW - Sweden, US - United States

Notes:

All numbers are rounded to the nearest million. The first two columns illustrate the amount of tax revenue received from levying withholding tax on royalty outflows of a country. Columns 3 and 4 depict the value of foreign withholding taxes credited in the respective country. For France, we calculate the tax credit for two scenarios: 1 . We assume that the IP Box regime does not apply (first value in columns 3 and 4 ) and 2 . We assume that all royalties are taxed under the IP Box regime (second value in columns 3 and 4). Columns 5 and 6 show the balance of withholding tax income minus withholding tax credit. For the EU member states, we calculate a range for withholding tax revenue, credit and balance, assuming that at least $50 \%$ (columns 1,3 , and 5) and at most $100 \%$ (Columns 2, 4, and 6) of all royalty payments were made between at least $25 \%$ affiliates qualifying for withholding tax reduction under the IRD. The columns 7-9 illustrate the withholding tax revenue, withholding tax credit and balance that would have resulted if all EU and OECD member states had levied withholding tax on royalties at a minimum rate of $10 \%$. Columns 10 and 11 highlight the change in withholding tax balance resulting from the reform option of a broader levy of withholding tax on royalties. For France, the second number in columns 10 and 11 depicts the change in tax revenue if IP Box regimes are considered. 
Table 5: Tax revenue effect of the inverted tax credit: all scenarios

\begin{tabular}{|c|c|c|c|c|c|c|c|c|c|c|}
\hline & \multicolumn{4}{|c|}{ ITC in addition to WHT } & \multicolumn{6}{|c|}{ ITC instead of WHT } \\
\hline $\begin{array}{l}\text { Millions of } \\
\text { USD }\end{array}$ & $\begin{array}{r}\Delta \text { Status Quo } \\
50 \% \text { IG } \\
\text { no IP Box }\end{array}$ & $\begin{array}{r}\Delta \text { Status Quo } \\
100 \% \text { IG } \\
\text { no IP Box }\end{array}$ & $\begin{array}{r}\Delta \text { Status Quo } \\
50 \% \text { IG } \\
\text { IP Box }\end{array}$ & $\begin{array}{r}\Delta \text { Status Quo } \\
100 \% \text { IG } \\
\text { IP Box }\end{array}$ & $\begin{array}{r}\Delta \text { Status Quo } \\
50 \% \text { IG } \\
\text { no IP Box } \\
\text { IG WHT }\end{array}$ & $\begin{array}{r}\Delta \text { Status Quo } \\
50 \% \text { IG } \\
\text { no IP Box } \\
\text { all WHT }\end{array}$ & $\begin{array}{r}\Delta \text { Status Quo } \\
100 \% \text { IG } \\
\text { no IP Box }\end{array}$ & $\begin{array}{r}\Delta \text { Status Quo } \\
50 \% \text { IG } \\
\text { IP Box } \\
\text { IG WHT }\end{array}$ & $\begin{array}{r}\Delta \text { Status Quo } \\
50 \% \text { IG } \\
\text { IP Box } \\
\text { all WHT }\end{array}$ & $\begin{array}{r}\Delta \text { Status Quo } \\
100 \% \text { IG } \\
\text { IP Box }\end{array}$ \\
\hline \multicolumn{11}{|l|}{ AT } \\
\hline 2006 & 3 & 7 & 4 & 9 & 5 & -30 & 10 & 6 & -29 & 13 \\
\hline 2007 & 4 & 7 & 10 & 20 & 7 & -31 & 13 & 13 & -25 & 26 \\
\hline 2008 & 5 & 11 & 13 & 26 & 9 & -27 & 18 & 17 & -19 & 34 \\
\hline 2009 & 5 & 9 & 12 & 23 & 8 & -16 & 17 & 15 & -9 & 30 \\
\hline 2010 & 7 & 15 & 16 & 31 & 11 & -13 & 21 & 19 & -5 & 38 \\
\hline 2011 & 8 & 16 & 22 & 44 & 10 & -12 & 20 & 24 & 2 & 48 \\
\hline 2012 & 11 & 21 & 23 & 47 & 12 & -10 & 25 & 25 & 2 & 50 \\
\hline \multicolumn{11}{|l|}{$\mathrm{CZ}$} \\
\hline 2006 & 2 & 5 & 6 & 12 & -18 & -38 & -37 & -15 & -35 & -30 \\
\hline 2007 & 3 & 7 & 12 & 24 & -20 & -43 & -41 & -12 & -35 & -23 \\
\hline 2008 & 2 & 5 & 9 & 19 & -25 & -52 & -50 & -18 & -45 & -36 \\
\hline 2009 & 2 & 5 & 8 & 16 & -23 & -47 & -46 & -18 & -42 & -35 \\
\hline 2010 & 2 & 3 & 5 & 10 & -25 & -49 & -49 & -21 & -46 & -42 \\
\hline 2011 & 2 & 4 & 11 & 22 & -10 & -44 & -21 & -1 & -35 & -3 \\
\hline 2012 & 1 & 3 & 9 & 18 & -8 & -29 & -16 & 0 & -22 & -1 \\
\hline \multicolumn{11}{|l|}{ DE } \\
\hline 2006 & 244 & 488 & 286 & 573 & 270 & 292 & 539 & 312 & 334 & 623 \\
\hline 2007 & 306 & 612 & 467 & 934 & 329 & 350 & 659 & 490 & 511 & 980 \\
\hline 2008 & 119 & 238 & 280 & 561 & 158 & 198 & 316 & 319 & 360 & 639 \\
\hline 2009 & 231 & 461 & 630 & 1259 & 284 & 318 & 568 & 683 & 717 & 1366 \\
\hline 2010 & 185 & 370 & 373 & 746 & 240 & 291 & 480 & 428 & 479 & 856 \\
\hline 2011 & 190 & 379 & 443 & 886 & 239 & 291 & 479 & 493 & 544 & 986 \\
\hline 2012 & 212 & 424 & 465 & 931 & 259 & 318 & 519 & 513 & 571 & 1025 \\
\hline \multicolumn{11}{|l|}{ DK } \\
\hline 2006 & 13 & 26 & 16 & 31 & 27 & 40 & 54 & 30 & 43 & 59 \\
\hline 2007 & 8 & 16 & 21 & 43 & 35 & 62 & 69 & 48 & 75 & 96 \\
\hline 2008 & 12 & 24 & 33 & 65 & 52 & 94 & 104 & 73 & 115 & 146 \\
\hline 2009 & 10 & 20 & 27 & 53 & 34 & 46 & 68 & 51 & 63 & 101 \\
\hline 2010 & 10 & 21 & 23 & 47 & 32 & 48 & 63 & 45 & 61 & 89 \\
\hline 2011 & 19 & 37 & 46 & 91 & 45 & 70 & 90 & 72 & 97 & 144 \\
\hline 2012 & 16 & 32 & 40 & 80 & 34 & 50 & 68 & 58 & 75 & 116 \\
\hline \multicolumn{11}{|l|}{ FR } \\
\hline 2006 & 73 & 146 & 2 & 5 & 136 & 184 & 271 & 65 & 113 & 130 \\
\hline 2007 & 111 & 222 & 12 & 24 & 210 & 287 & 420 & 111 & 188 & 222 \\
\hline 2008 & 145 & 289 & 22 & 43 & 265 & 366 & 530 & 142 & 243 & 284 \\
\hline 2009 & 210 & 420 & 44 & 87 & 232 & 217 & 463 & 65 & 50 & 130 \\
\hline 2010 & 249 & 497 & 90 & 180 & 277 & 272 & 554 & 118 & 112 & 237 \\
\hline 2011 & 298 & 596 & 138 & 275 & 332 & 326 & 665 & 172 & 164 & 344 \\
\hline 2012 & 269 & 539 & 119 & 239 & 287 & 278 & 575 & 137 & 127 & 275 \\
\hline \multicolumn{11}{|l|}{ IL } \\
\hline 2006 & 11 & 21 & 13 & 25 & -8 & -26 & -15 & -6 & -24 & -11 \\
\hline 2007 & 14 & 28 & 18 & 35 & 7 & 0 & 13 & 10 & 3 & 21 \\
\hline 2008 & 15 & 30 & 20 & 40 & 1 & -13 & 2 & 6 & -8 & 12 \\
\hline 2009 & 1 & 1 & 6 & 11 & 5 & 10 & 11 & 10 & 15 & 21 \\
\hline 2010 & 1 & 1 & 5 & 11 & 7 & 13 & 13 & 11 & 18 & 23 \\
\hline 2011 & 1 & 1 & 6 & 12 & 11 & 21 & 21 & 16 & 26 & 32 \\
\hline 2012 & 1 & 2 & 8 & 16 & 12 & 24 & 25 & 19 & 31 & 39 \\
\hline \multicolumn{11}{|l|}{ IT } \\
\hline 2006 & 47 & 95 & 64 & 128 & 41 & 3 & 82 & 57 & 20 & 115 \\
\hline 2007 & 53 & 106 & 85 & 171 & 45 & 10 & 90 & 77 & 43 & 154 \\
\hline 2008 & 197 & 394 & 401 & 803 & 152 & -8 & 305 & 357 & 196 & 713 \\
\hline 2009 & 185 & 370 & 367 & 734 & 181 & 69 & 362 & 363 & 252 & 726 \\
\hline 2010 & 196 & 393 & 403 & 806 & 180 & 56 & 360 & 387 & 263 & 774 \\
\hline 2011 & 196 & 393 & 451 & 903 & 181 & 52 & 361 & 436 & 307 & 871 \\
\hline 2012 & 172 & 344 & 398 & 796 & 159 & 50 & 319 & 385 & 277 & 771 \\
\hline \multicolumn{11}{|l|}{ JP } \\
\hline 2006 & 303 & 605 & 338 & 676 & 307 & 312 & 615 & 343 & 348 & 686 \\
\hline 2007 & 342 & 684 & 417 & 833 & 330 & 319 & 660 & 405 & 393 & 810 \\
\hline 2008 & 454 & 907 & 549 & 1099 & 419 & 384 & 838 & 515 & 480 & 1030 \\
\hline 2009 & 450 & 900 & 532 & 1063 & 374 & 298 & 748 & 456 & 380 & 912 \\
\hline 2010 & 532 & 1063 & 620 & 1239 & 425 & 318 & 849 & 513 & 406 & 1025 \\
\hline 2011 & 560 & 1120 & 686 & 1372 & 448 & 335 & 895 & 574 & 462 & 1148 \\
\hline 2012 & 522 & 1045 & 663 & 1326 & 423 & 324 & 846 & 564 & 464 & 1127 \\
\hline
\end{tabular}




\begin{tabular}{|c|c|c|c|c|c|c|c|c|c|c|}
\hline \multicolumn{11}{|l|}{ KR } \\
\hline 2006 & 5 & 10 & 17 & 34 & -239 & -484 & -479 & -227 & -472 & -454 \\
\hline 2007 & 9 & 18 & 31 & 61 & -257 & -523 & -515 & -236 & -502 & -471 \\
\hline 2008 & 7 & 14 & 31 & 62 & -290 & -588 & -581 & -267 & -564 & -533 \\
\hline 2009 & 4 & 7 & 24 & 49 & -331 & -666 & -662 & -310 & -645 & -621 \\
\hline 2010 & 4 & 9 & 23 & 46 & -457 & -919 & -914 & -439 & -900 & -877 \\
\hline 2011 & 4 & 8 & 19 & 37 & -299 & -601 & -597 & -284 & -587 & -568 \\
\hline \multicolumn{11}{|l|}{ SK } \\
\hline 2006 & 0 & 1 & 0 & 1 & 2 & 0 & 3 & 2 & 0 & 3 \\
\hline 2007 & 0 & 1 & 1 & 2 & 2 & 1 & 5 & 3 & 2 & 6 \\
\hline 2008 & 0 & 0 & 3 & 6 & 2 & -1 & 4 & 5 & 1 & 10 \\
\hline 2009 & 0 & 0 & 1 & 3 & 0 & -4 & 0 & 1 & -3 & 2 \\
\hline 2010 & 0 & 0 & 1 & 3 & -1 & -6 & -2 & 0 & -5 & 0 \\
\hline 2011 & 0 & 0 & 1 & 2 & -2 & -8 & -3 & -1 & -7 & -2 \\
\hline 2012 & 0 & 0 & 1 & 2 & -1 & -6 & -2 & 0 & -5 & -1 \\
\hline \multicolumn{11}{|l|}{ sw } \\
\hline 2006 & 7 & 14 & 9 & 17 & 21 & 38 & 43 & 23 & 39 & 46 \\
\hline 2007 & 12 & 24 & 29 & 59 & 28 & 44 & 56 & 46 & 62 & 91 \\
\hline 2008 & 26 & 51 & 47 & 93 & 38 & 51 & 76 & 59 & 72 & 118 \\
\hline 2009 & 12 & 24 & 31 & 62 & 20 & 28 & 40 & 39 & 48 & 79 \\
\hline 2010 & 17 & 33 & 35 & 71 & 38 & 55 & 75 & 56 & 74 & 113 \\
\hline 2011 & 20 & 40 & 42 & 84 & 34 & 53 & 69 & 56 & 75 & 113 \\
\hline 2012 & 35 & 70 & 66 & 131 & 45 & 62 & 90 & 76 & 93 & 152 \\
\hline \multicolumn{11}{|l|}{ US } \\
\hline 2006 & 1027 & 1118 & 1318 & 1409 & 1444 & 1871 & 1450/1962 & 1735 & 2162 & $1741 / 2253$ \\
\hline 2007 & 1377 & 1452 & 1824 & 1900 & 1854 & 2387 & $1874 / 2463$ & 2302 & 2835 & $2322 / 2911$ \\
\hline 2008 & 2214 & 2214 & 2711 & 2711 & 2620 & 3280 & $2620 / 3280$ & 3117 & 3776 & $3117 / 3776$ \\
\hline 2009 & 2493 & 2493 & 2909 & 2909 & 2838 & 3491 & $2838 / 3491$ & 3254 & 3907 & $3254 / 3907$ \\
\hline 2010 & 2182 & 2187 & 2718 & 2723 & 2763 & 3536 & $2762 / 3541$ & 3299 & 4072 & $3298 / 4078$ \\
\hline 2011 & 2425 & 2452 & 3311 & 3338 & 3079 & 3919 & $3058 / 3945$ & 3965 & 4805 & $3944 / 4831$ \\
\hline 2012 & 3065 & 3072 & 3998 & 4005 & 3281 & 4219 & $3279 / 4226$ & 4213 & 5152 & $4212 / 5159$ \\
\hline
\end{tabular}

Abbreviations:

ITC - Inverted Tax Credit, WHT - Withholding Tax, IG - intra-group, AT - Austria, CZ - Czech Republic, DE - Germany, DK - Denmark, FR - France, IL - Israel, IT - Italy, JP - Japan, KR - Republic of Korea, SK Slovak Republic, SW - Sweden, US - United States

Notes:

All numbers are rounded to the nearest million. Columns 1-4 depict the range of additional tax revenue income that in the respective years would have resulted from the implementation of an inverted tax credit system in addition to existing withholding taxes. The lower boundary is calculated assuming that at least $50 \%$ of all royalty payments were made between affiliates and thus were subject to the inverted tax credit (columns 1 and 3). The upper boundary is calculated assuming that all payments were made between affiliates (columns 2 and 4). In columns 1 and 2, we consider the case that no royalty income benefits from an IP Box regime. In columns 3 and 4 , we assume that all royalty income benefits from an IP Box regime, where available. Columns 5-10 present our results for the case that the inverted tax credit replaces withholding taxes in all OECD and EU member states. In columns 5, 6, 8 and 9, we assume that $50 \%$ of all royalty payments were made between affiliates. In columns 7 and 10, we assume 100\% affiliate payments. In columns 5-7, IP Box regimes are not considered, in columns 810, we assume that all royalty income benefits from an IP Box regime, where available. In columns 5 and 8 , we consider the case that only withholding taxes on intra-group royalties are replaced. In columns 6 and 9, we assume that all withholding taxes are replaced. For the U.S., in columns 7 and 10, the first value refers to the change in revenue if only withholding taxes on intra-group royalties are replaced and the second value refers to the change in revenue if withholding taxes on all royalties are replaced. The reason why those values differ only for the U.S. is that we use the more detailed BEA data for the U.S., which for most royalty flows shows the share of affiliate payments. 


\section{References}

Becker, J./Fuest, C. (2012), Transfer pricing and the intensity of tax rate competition, Economics Letters, pp. 146-148.

BEA (2014), U.S. International Services, Detailed statistics for cross-border trade, Royalties and License Fees, 2006-2012, http://www.bea.gov/international/xls/tab4a.xls.

Blouin, J./Huizinga, H.P./Laeven, L./Nicodème, G. (2014),Thin Capitalization Rules and Multinational Firm Capital Structure, CESifo Working Paper No. 4695, Munich.

Bohn, A. (2009), Zinsschranke und Alternativmodelle zur Beschränkung des steuerlichen Zinsabzugs, in: Herzig, W./Watrin, C. (Eds.), Forschungsreihe Rechnungslegung und Steuern, Gabler Verlag.

Buettner, T./Overesch, M./Schreiber, U./Wamser, G. (2008), The impact of thin-capitalization rules on multinationals' financing and investment decisions, Deutsche Bundesbank Discussion Paper No. 03/2008, Frankfurt am Main.

Buettner, T./Overesch, M./Schreiber, U./Wamser, G. (2012), The Impact of ThinCapitalization Rules on the Capital Structure of Multinational Firms, Journal of Public Economics, pp. 930-938.

Buettner, T./Overesch, M./Wamser, G. (2014): Anti Profit-Shifting Rules and Foreign Direct Investment, CESifo Working Paper No. 4710, Munich.

Burnett, C. (2014), Intra-Group Debt at the Crossroads: Stand-Alone versus Worldwide Approach, World Tax Journal, pp. 40-76.

Buslei, H./Simmler, M.(2012), The Impact of Introducing an Interest Barrier - Evidence from the German Corporation Tax Reform 2008, DIW Discussion Paper No. 1215, Berlin.

Desai, M.A./Foley, C.F./Hines, J.R. (2004), A Multinational Perspective on Capital Structure Choice and Internal Capital Markets, The Journal of Finance, pp. 2451-2487.

Dischinger, M./Riedel, N. (2011), Corporate taxes and the location of intangible assets within multinational firms, Journal of Public Economics, pp. 691-707.

Dreßler, D./Scheuering, U. (2012), Empirical Evaluation of Interest Barrier Effects, ZEW Discussion Paper No. 12-046, Mannheim.

Ernst \& Young (2006-2012), Worldwide Corporate Tax Guides for 2006-2012. 
European Commission (2011), Proposal for a Council Directive on a Common Consolidated Corporate Tax Base (CCCTB), COM(2011) 121/4, Brussels.

European Commission (2012a), Communication from the Commission to the European Parliament and the Council - An Action Plan to strengthen the fight against tax fraud and tax evasion, COM(2012) 722 final, Brussels.

European Commission (2012b), Commission Recommendation of 6.12 .2012 regarding measures intended to encourage third countries to apply minimum standards of good governance in tax matters, C(2012) 8805 final, Brussels.

Evers, L./Miller, H./Spengel, C. (2014), Intellectual Property Box Regimes: Effective Tax Rates and Tax Policy Considerations, International Tax and Public Finance, DOI 10.1007/s10797-014-9328-x.

Feld, L.P./Heckemeyer, J.H./Overesch, M. (2013), Capital Structure Choice and Company Taxation: A Meta-Study, Journal of Banking and Finance, pp. 2850-2866.

Fuest, C./Spengel, C./Finke, K./Heckemeyer, J.H./Nusser, H. (2013), Profit Shifting and “Aggressive” Tax Planning by Multinational Firms: Issues and Options for Reform, World Tax Journal, pp. 307-324.

Grubert, H. (2003), Intangible Income, Intercompany Transactions, Income Shifting, and the Choice of Location, National Tax Journal, pp. 221-242.

Henry T./Nikolakakis, A,/Bontes, D. (2008), Thin Capitalization Regimes in Selected Countries, Report Prepared for the Advisory Panel on Canada’s System of International Taxation, http://publications.gc.ca/collections/collection_2010/fin/F34-3-6-2009eng.pdf.

Hong, Q. /Smart, M. (2010), In Praise of Tax Havens: International Tax Planning and Foreign Direct Investment, European Economic Review, pp. 82-95.

Huizinga, H.P./Laeven, L./Nicodeme, G. (2008), Capital structure and international debt shifting, Journal of Financial Economics, pp. 80-118.

Johannesen, N. (2012), Optimal Fiscal Barriers to International Economic Integration in the Presence of Tax Havens, Journal of Public Economics, pp. 400-416. 
Kalloe, V. (2011), European Union - Corporate Tax Treatment of Interest: EU State Aid and the EU Code of Conduct as a Means of Combating Harmful Tax Competition, European Taxation, pp. 504-514.

Karkinsky, T./Riedel, N. (2012), Corporate taxation and the choice of patent location within multinational firms, Journal of International Economics, pp. 176-185.

Keen, M. (2001), Preferential Regimes Can Make Tax Competition Less Harmful, National Tax Journal, pp. 757-762.

Kessler, W./Eicke, R. (2008), The Emergence of R\&D Tax Regimes in Europe, Tax Notes International, pp. 845-847.

Kleinbard, E.D. (2011), Stateless Income, Florida Tax Review, pp. 699-773.

KPMG (2014), Corporate tax rates table, available online from http://www.kpmg.com/global/en/services/tax/tax-tools-and-resources/pages/corporatetax-rates-table.aspx.

Lodin, S.-O. (2011), Intragroup Lending in Sweden - A Vehicle for International Tax Arbitrage, Tax Notes International, pp. 177-180.

Lodin, S.-O. (2013), Intragroup Royalties as a Vehicle for International Tax Arbitrage, Tax Notes International, pp. 1317-1319.

Lohse, T./Riedel, N. (2013), Do Transfer Pricing Laws Limit International Income Shifting? Evidence from European Multinationals, CESifo Working Paper No. 4404.

Mutti, J./Grubert, H. (2009), The effect of taxes on royalties and the migration of intangible assets abroad, in: International trade in services and intangibles in the era of globalization, University of Chicago Press, Chicago.

OECD (2013), Action Plan on Base Erosion and Profit Shifting, OECD Publishing, Paris.

OECD (2014), OECD.Stat database, http://stats.oecd.org.

Overesch, M. (2009), The Effects of Multinationals' Profit Shifting Activities on Real Investments, National Tax Journal, pp. 5-23.

Overesch, M./Wamser, G. (2010), Corporate Tax Planning and Thin-Capitalization Rules: Evidence from a Quasi-Experiment, Applied Economics, pp. 563-573. 
Ruf, M./Schindler, D. (2012), Debt Shifting and Thin-Capitalization Rules - German Experience and Alternative Approaches, NHH Discussion Paper RRR No. 06-2012, Bergen.

Sandell, J. (2012), The Double Irish and the Dutch Sandwich: How Some U.S. Companies Are Flummoxing the Tax Code, Tax Notes International, pp. 867-878.

Slemrod, J. B./Wilson, J. D. (2009), Tax Competition with Parasitic Tax Havens, Journal of Public Economics, pp. 1261-1270.

Sullivan, M.A. (2012), Economic Analysis: Should Tech and Drug Firms Pay More Tax?, Tax Notes International, pp. 655-656.

Wamser, G. (2008), The Impact of Thin-Capitalization Rules on External Debt Usage - A Propensity Score Matching Approach, ifo Working Paper No. 62, Munich.

Webber, S. (2010), Thin Capitalization and Interest Deduction Rules: A Worldwide Survey, Tax Notes International, pp. 683-708.

Weichenrieder, A.J./Windischbauer, H. (2008), Thin-Capitalization Rules and Company Responses: Experience from German Legislation, CESifo Working Paper No. 2456, Munich.

WIPO (2014), IP Statistics Data Center, http://ipstats.wipo.int/ipstatv2/.

Zinn, T./Riedel, N./Spengel, C. (2014), The Increasing Importance of Transfer Pricing Regulations - a Worldwide Overview, Intertax, pp. 352-404. 